\title{
Evolution, roots and influence of the literature on National Systems of Innovation: a bibliometric account
}

\author{
Aurora A. C. Teixeira ${ }^{\star}$
}

The literature on the National Systems of Innovation (NSI) is a relatively new field of research that has spread remarkably in the past 20 years. This article offers a complementary, quantitative description of the state-of-the-art of the literature based on bibliometric methods, by explicitly addressing the roots, evolution and influence of NSI literature. The exercise shows that over time the rate of published articles was quite irregular and that contributions on NSI have not (yet) converged to an integrated analytical framework. Although historically detailed descriptions on NSI showed a noticeable increase in the more recent period (2006-2010) analyses using more formal and diversified quantitative methodologies for assessing the performance of NSI remained lacking, reflecting its persisting methodological weaknesses. The roots of the NSI literature can be found at the core of innovation studies by certain well-known scholars in the area of economics of innovation and science policy research. Even though publications on NSI are falling in relative importance and are highly concentrated on a small set of countries (United Kingdom, Denmark, and the United States), their influence is global. They are cited by authors affiliated in organisations around the world, notably in Latin America and Asia. Such an influence goes far beyond the area of innovation studies and has resonated in fields such as economic geography, environmental studies, international business and managerial sciences. This demonstrates that the NSI literature is not self-referential.

Key words: National Systems of Innovation, Bibliometrics, Roots, Influence FEL classifications: $\mathrm{O} 10, \mathrm{O} 30, \mathrm{C} 89$

The notion of the 'national system of innovation' [is] one of the most important concepts to emerge in the field of innovation studies over the last 25 years. (Martin and Bell, 2011, p. 896)

\section{Introduction}

From the late 1980s onwards a new approach emerged, based on the concept of National Systems of Innovation (NSI) (Lundvall, 1992; Nelson, 1993). Rather than focussing on various aspects of innovation in isolation, this approach encompasses a

Manuscript received 7 August 2008; final version received 5 November2012.

Address for correspondence: Faculdade de Economia do Porto, Rua Dr Roberto Frias, 4200-464 Porto, Portugal; email: ateixeira@fep.up.pt

${ }^{\star}$ CEF.UP; Faculdade de Economia, Universidade do Porto, INESC Porto; OBEGEF. The author is deeply indebted to two anonymous referees for their valuable insights. The usual disclaimers apply. This paper is dedicated to Chris Freeman (1921-2010).

(C) The Author 2013. Published by Oxford University Press on behalf of the Cambridge Political Economy Society. All rights reserved. 


\section{Page 2 of 34 A. A. C. Teixeira}

more holistic perspective, emphasising the role of interaction between different actors and how this interaction is influenced by broader social, institutional and political factors (Fagerberg et al., 2009; Fagerberg and Verspagen, 2009).

The diffusion of the NSI approach has been surprisingly rapid and is now widely used both in academic circles and policy contexts. Indeed, several studies (e.g., Fagerberg, 2003; Balzat and Hanusch, 2004; Groenewegen and van der Steen, 2006; Lorentzen, 2009; Yoon and Hyun, 2009) confirm that the literature on NSI is a relatively new and rapidly growing field of research. In addition, the approach also finds broad applications in policy contexts - by regional authorities and national governments, as well as by international organisations such as the Organisation for Economic Co-operation and Development (OECD), the European Union, United Nations Conferene and Trade and Development (UNCTAD) and United Nations Industrial Development Organization (UNIDO) (Edquist, 2005; Sharif, 2006). According to Lundvall (2007), the diffusion of the NSI approach is quite impressive taking into account that 20 years ago only a handful of academics had heard of the concept.

The NSI can be seen as an analytical framework (Sun and Liu, 2010), which serves as both model and tool, emphasising the systemic characteristics of innovation, rapid technological change and globalisation. In this line, the NSI approach can be useful as a general framework to study the differences between the productive and research systems of countries, making it possible to analyse absorptive capacities and the learning capability of individuals and organisations that take part in innovation processes (Álvarez and Marín, 2010).

Despite the wide recognition of the intrinsic worth of the NSI approach, criticisms abound. Some argue that there is plenty of description but little analysis in the NSI literature (Lorentzen, 2009); it is still excessively constrained by a narrow focus, in terms of concepts and policy practice, on advanced economies (Fagerberg and Srholec, 2008); it offers little guidance for testable propositions and policy recommendation for the developing world (Lundvall, 2007; Albuquerque, 2007; Lorentzen, 2009); it has little operational value and is difficult to implement (OECD, 2002). One of the most acute problems in the NSI approach is highlighted by Godin (2009): the insufficiency of formal studies that tackle the issues of devising appropriate tools to measure the concept and establishing sound methodological guidelines to empirical system mapping, namely, in less developed regions/countries. Even Lundvall (2002), one of the most notable contributors to the NSI literature, recognises that the performance indicators devised to reflect the efficiency and effectiveness of NSI in producing and exploiting economically useful knowledge are under-developed.

In recent years, excellent theoretical surveys focussing on NSI were published (e.g., Edquist, 2005; Carlsson, 2006; Lundvall, 2007; Godin, 2009; Fagerberg and Sapprasert, 2011) but to the best of my knowledge, there is a lack of quantitative, bibliometrically based surveys on this matter. Existing surveys offer a focussed (and indepth) perspective, without generally providing a comprehensive picture and the relative positioning of topics within the NSI literature. Bibliometric tools and bibliometric surveys permit, in complement to these more qualitatively led surveys, an analysis of recent paths in a given research field (Teixeira, 2011) and an objective assessment of the seminal contributions and contributors (Du and Teixeira, 2012). In addition, they contribute to shedding light on the heated debate on the relative strength and limitations of the NSI framework by assessing the dynamics of particular types of methodologies (formal versus appreciative and empirical) and themes (e.g., historical accounts, policy-related issues). 
There are a few high-quality studies on NSI that resort to bibliometrics, but their focus is not on assessing the roots, evolution and influence of this literature. Rather, they are centred on empirically analysing several dimension of the innovation systems, namely, the collaborative structure of research systems (Toivanen and Ponomariov, 2011) and the relationship between national scientific capabilities, the science intensity of technology and technological performance, both within industrial fields (van Looy et al., 2006) and between countries (Choung and Hwang, 2000).

Through citation analysis, I seek to uncover the origin of the main ideas behind NSI and assess whether the literature is largely self-referential or has also had an impact in other literatures. ${ }^{1}$ Such a bibliometric exercise can foster discussion and put into perspective existing criticisms regarding the NSI approach, namely excessively rhetorical, too descriptive and methodologically fragile (Fagerber and Srholec, 2008; Yoon and Hyun, 2009; Guan and Chen, 2012) and vague policy insights (Lorentzen, 2009).

This article is structured as follows. In the next section I present a taxonomy for categorising the main topics within the NSI approach. Then Section 3 describes the methodological underpinnings of the research. The bibliometric exercises, most specifically, the general trends of the NSI literature in the past 20 years (themes analysed, type of studies, main outlets), the roots and range of influence of the NSI literature is put forward in Section 4 . Section 5 concludes.

\section{Main topics within NSI literature}

The vast amount of analytical work and studies using the NSI concept makes it difficult to establish a classification. Since the late 1990s, several attempts have been made to evaluate and compare innovation systems in terms of their performance, which in turn is defined and measured in different ways. In some cases, comparative studies on the system level have been used as a preliminary step to generate rankings of national innovation systems (see, e.g., Porter and Stern, 2002). Studies on NSI have been classified in policy-oriented studies and in research-driven advances of the NSI approach (see Table 1).

The systemic approach to innovation enjoys growing popularity among technology policy makers as a means by which to derive technology policy implications (Nelson, 1984) due to the pragmatic assumptions underlying the NSI concept and the insightful outcomes gained so far in studies on national innovation patterns (Samara et al., 2012). At the same time, learning processes from each country's experience and from the experience of other countries in the organisation of national innovation systems are recognised as an important input to innovation policy design (Lundvall, 2000, 2003). This awareness calls for broad international comparisons of innovative strength and institutional frameworks, especially of incentive mechanisms to innovative action.

We are currently witnessing an intended convergence between two conflicting methodological streams, namely, a systemic perception of innovation processes with strong country-specific features, on the one hand, and objectives to obtain clear-cut policy recommendations through benchmarking exercises, on the other (Balzat and Hanusch, 2004; Sharif, 2006; Lundvall, 2007). Typically, the intended 'benchmarking studies' follow, at least implicitly, a two-step procedure (Balzat and Hanusch,

\footnotetext{
${ }^{1}$ I acknowledge one of the referees for bringing up this aspect.
} 
Page 4 of 34 A. A. C. Teixeira

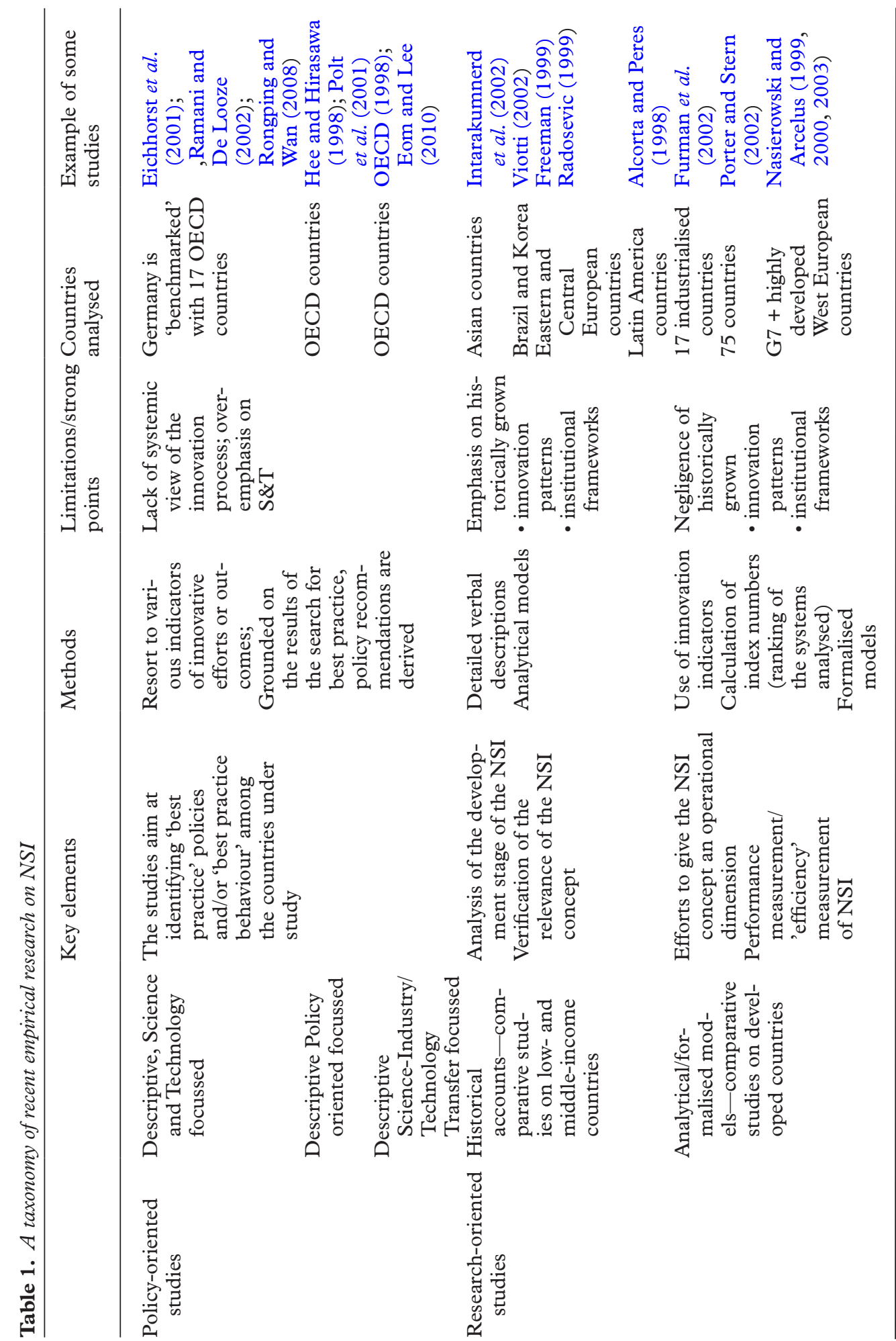




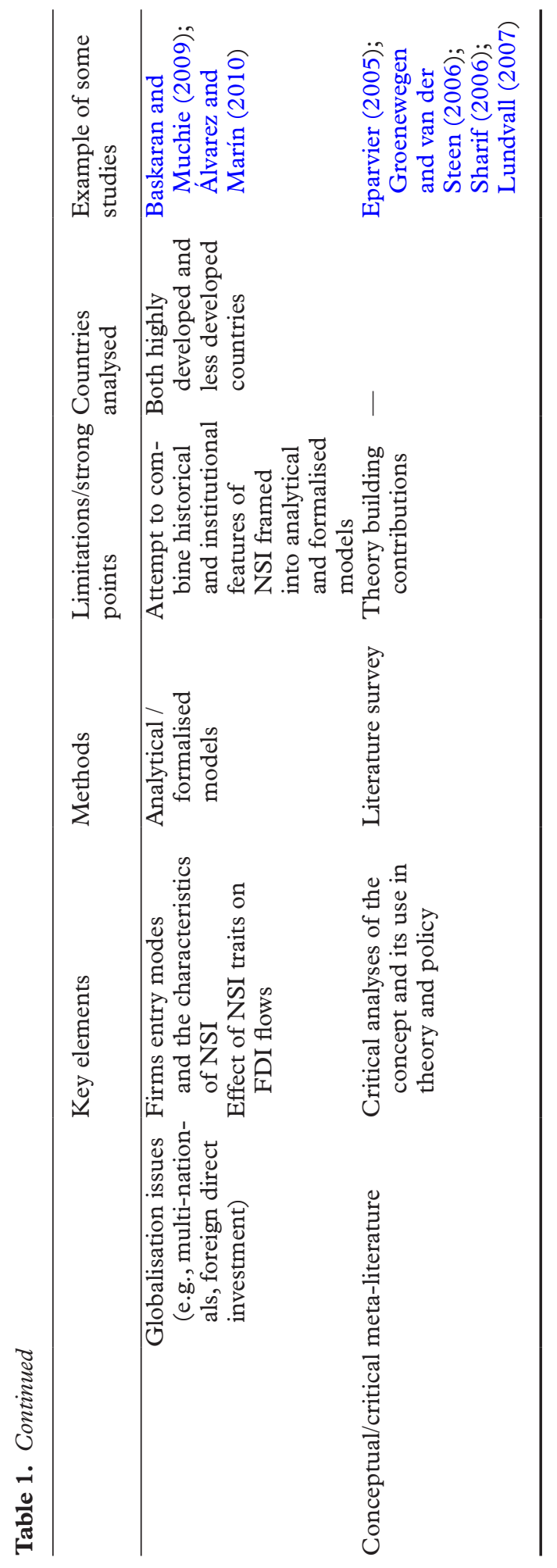




\section{Page 6 of 34 A. A. C. Teixeira}

2004). First, by resorting to various indicators of innovative efforts or outcomes, the studies aim to identify 'best practice' policies and/or 'best practice behaviour' among the countries under study. In a second step, and grounded on the results of the search for best practice, policy recommendations are derived. In this broad group of policy-oriented studies it is relevant to distinguish three sub-groups: 1) those whose focus is mainly on science and technology issues (e.g., Eichhorst et al., 2001; Ramani and De Looze, 2002; Rongping and Wan, 2008); 2) the ones particularly focussed on policies (e.g., Hee and Hirasawa, 1998; Polt et al., 2001); and 3) those concerned with science-industry and technology transfer issues (OECD, 1998; Eom and Lee, 2010).

Apart from this political background, research aims in the economics of innovation literature can be observed as the second main driver towards comparative studies of NSI. To explain this argument, recall some of the limitations of earlier NIS studies and of the research course pursued. First, these early studies have typically given descriptive accounts of national innovation patterns, whilst the number of indicators used regarding innovative activity has been rather small (Godinho et al., 2004). Second, early NSI studies usually concentrated on one country to thoroughly describe the functioning of the innovation system under consideration (Lundvall, 2007). Third, the set-up of NSI studies has varied considerably because of the lack of a formalised methodology to conduct such studies (Edquist, 2005).

These limitations may have stimulated research efforts to carry out detailed systemlevel comparisons as well as formalise the NSI concept. These efforts have led to the diffusion, in a larger scale, of historically driven studies on low- and middle-income countries (Fagerberg and Srholec, 2008; Lorentzen, 2009; Guennif and Ramani, 2012), and the development of formalised models, more concentrated on developed countries (Nasierowski and Arcelus, 1999, 2000; Furman et al., 2002). The issue of globalisation and innovation systems has also attracted considerable research (e.g., Baskaran and Muchie, 2009; Álvarez and Marín, 2010).

Apart from descriptive and empirically led studies, critical meta-literature on innovation systems has been quite relevant in the field. One of the first interesting critical analyses of the concept and its use in theory and policy is by Miettinen (2002). But other more recent and comprehensive works such as those by Eparvier (2005), Groenewegen and van der Steen (2006), Sharif (2006), Lundvall (2007), Godin (2009), and Fagerberg and Sapprasert (2011) also deserve to be included in this important and 'theory-building' category.

In summary of what has been said, publications on NSI might be categorized into seven main topics (see Table 1 ) plus a residual category 'Others': 1) conceptual/critical meta-literature; 2) descriptive science and technology-focussed; 3) descriptive policyoriented/focussed; 4) descriptive science-industry/technology transfer; 5) historical accounts; 6) globalisation issues; 7) analytical models.

\section{Methodological considerations}

To provide additional insight on the main trends of NSI research and its main scientific roots and influence, I have developed three major bibliometric exercises: 1) main trends on NSI: based on the analysis of the abstracts from all (356) articles published on NSI found in the Econlit and Scopus bibliographic databases up to 31 December 2010; 2) the scientific roots of NSI literature: citation analysis taking the references/citations of 
297 (out of the 356) articles listed in the abstract database, ${ }^{2}$ which generated a citation database involving 13,556 references/citations; 3) the influence of NSI literature: considering 25 'seminal' journal articles on NSI (i.e., articles that were cited in 30 and more studies), we constructed a database of 2,109 studies that were 'influenced' by the NSI literature.

As a basis for gathering the references, I used the EconLit and SciVerse Scopus bibliographic databases. The former is considered a fundamental research tool in economics, providing different types of information, from bibliographic citations, with selected abstracts, to international literature on economics since 1969. Although it covers a broad range of document types published worldwide, namely, journal articles, it leaves out journals (articles) from a broader social science scope, namely, from the political and sociological fields of knowledge. Scopus is the largest abstract and citation database of peer-reviewed literature, covering 16,500 peer-reviewed journals on scientific, technical, medical and social sciences topics. Thus, it includes social science journals that EconLit leaves out, for instance, Science and Public Policy and Technology in Society, which are important outlets in innovation studies.

The first database (main trends on NSI) was constructed by using the term 'National Innovation Systems' (or 'National Systems of Innovation') as the search keyword. The total number of analysed records was 356, and texts corresponding to comments, rejoinders and corrigenda were eliminated from the categorisation. Publications on the 'National Systems of Innovation' (NSI) were analysed in terms of seven main topics, which were selected on the basis of a review of the existing literature. These topics include: 1) conceptual/critical meta-literature; 2) descriptive science \& technologyfocussed; 3) descriptive policy-focussed; 4) descriptive science-industry/technology transfer; 5) historical accounts; 6) globalisation issues (e.g., multi-nationals, foreign direct investment); 7) formalised/analytical models; and 8) other.

Based on this classification, I assessed the relative weight of each topic of research and, most important, inferred the trends in NSI in the period in analysis.

Apart from the main topic of research, the articles were also classified according to the main method of research used. Following Silva and Teixeira $(2008,2009)$ and Cruz and Teixeira (2010), we considered six major classes: 1) formal, 2) appreciative, 3) formal and empirical, 4) appreciative and empirical, 5) empirical, and 6) surveys. ${ }^{3}$

Articles classified as 'formal' develop analytical models, and the theoretical explanations are expressed in mathematical terms (through modelling) or simulation. When articles classified as formal include data tests, they are classified as 'formal and empirical'. The classifications referred to as 'empirical' involve econometric or statistical tests. Those considered 'appreciative' refer to theoretical articles, more discussion in nature. Whenever articles defined as 'appreciative' include appreciations or comments based on empirical data, they are classified as 'appreciative and empirical'. Finally, when the articles involve an overview of the literature, they are called 'surveys'.

This categorisation not only enabled me to perform a full characterisation of the literature on NSI, but more important, it provided important pointers on the relationship between the increasing relevance of NSI and the (possibly) growing formalism in

\footnotetext{
2 Some papers were not publicly available, so it was not possible to gather the corresponding references.

3 The distinction between formal and appreciative theorising follows Nelson and Winter's (1982) original proposal and intends to separate the theoretical explanations that are expressed in mathematical terms (through modelling), from the theoretical work in which this kind of construction is absent.
} 


\section{Page 8 of 34 A. A. C. Teixeira}

the research methods used. The mathematisation of economics is probably the most important feature in the history of twentieth-century economics (Mirowski, 2002; Weintraub, 2002). The use of models has become the dominant practice-in the view of many, the best way of doing 'good economics'. It is therefore interesting to assess the extent to which the rise in interest in this NSI field is correlated with a change in the main methodologies undertaken.

The second database (the scientific roots of NSI) consisted in performing citation analysis taking the references/citations of 297 (out of the 356) articles listed in the abstract database. More precisely, a comprehensive analysis was conducted of the 13,556 references cited in all articles published to these articles. These references were collected by a copy-and-paste procedure from original articles and (for the more recent articles) from Scopus, which allows the references to be directly exported to an Excel file.

Given that the references were not uniformly cited in each of article, we then had to harmonise the references and only afterwards perform the citation analysis. ${ }^{4}$ Such a quantitative analysis helped me identify the most influential works in this area of research, at the same time providing important clues on the clustering of contributions.

\section{A bibliometric account of NSI-related studies}

\subsection{An overview of the studies published on NSI from 1991 to 2010}

The evolution over time of articles published on NSI is quite irregular (Figure 1). We could state that the true departure point of publishable academic research on NSI occurred in 1995, when the Cambridge fournal of Economics published a special issue on NSI, including articles by seminal authors such as Chris Freeman, Stan Metcalfe and David Mowery. An interesting pattern which arises here is that in general, the years that are associated with higher numbers of published articles coincide with the existence of special issues in renowned journals: Research Policy and Technology Analysis $\mathcal{E}$ Strategic Management in 1999; Research Policy in 2002; Industrial and Corporate Change and Science and Public Policy in 2004; Industry E Innovation in 2006; Science and Public Policy in 2007; Technology in Society in 2008.

Although the (absolute) number of journal articles focussed on NSI has been consistently growing since the beginning of the 1990s, the importance of NSI on innovation-related articles has been decreasing since its peak in 1995. This downwards trend has been particularly marked after 2004, which may indicate some exhaustion of (scientific and political) interest on the matter of NSI.

Around half of the journal articles published on NSI between 1991 and 2010 are descriptive accounts (Figure 2), focussing in particular on science and technology $(23.9 \%)$ and policy-oriented $(14.6 \%)$ issues. These two themes, however, lost importance over the period in analysis. Indeed, from the 1995-99 period to the most recent

\footnotetext{
${ }^{4}$ Most of the existing works involving citation analysis do not require such an painstaking, time-consuming effort as the majority of journals involved are indexed in Scopus or ISI Web of Knowledge (produced by Thomson Scientific), which automatically provides the references and corresponding citations. We opted for this manual procedure instead of resorting to the ISI or Scopus databases because not all articles on NSI had their references available in these databases. Additionally, the ISI only provides information on the first author, therefore supplying an incomplete picture of authors' contribution to the area.
} 


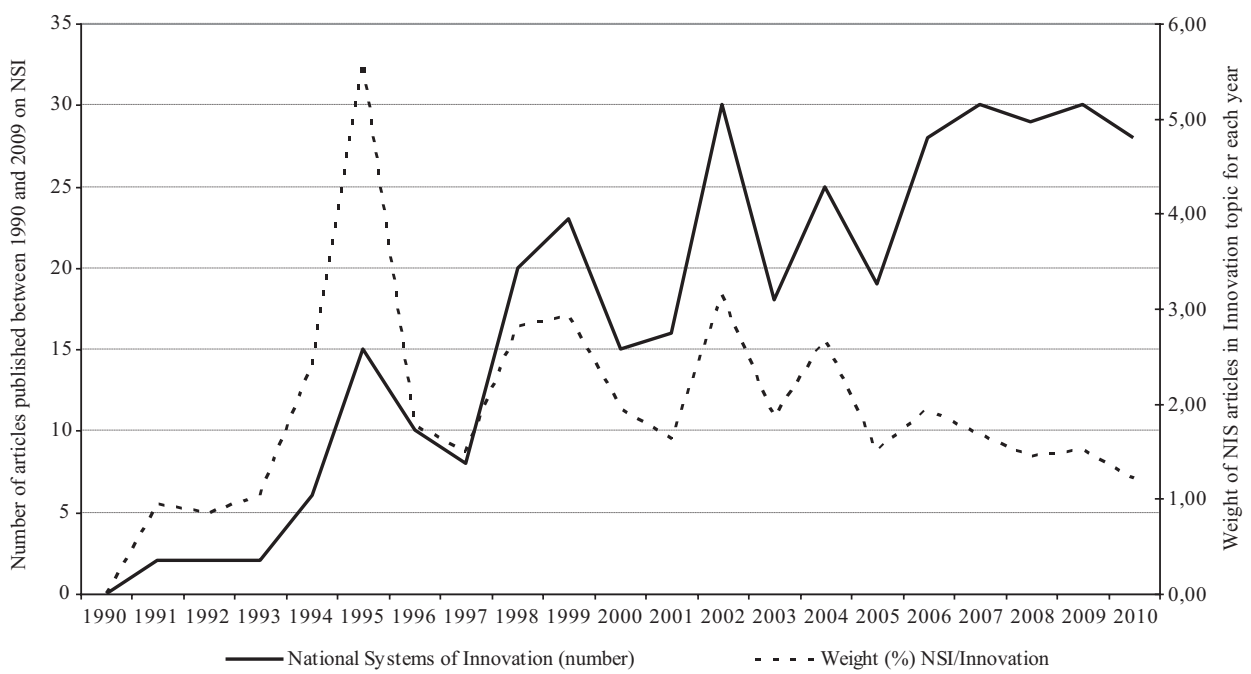

Fig. 1. Fournal articles published on NSI, by year, 1990-2010.

Notes: The 356 articles on NSI were obtained from the Econlit and Scopus bibliographic databases using National System of Innovation and its variations as search keywords (the search was limited to journal articles); the number of articles published on 'Innovation' (free search in all fields), 1990-2010, in the areas of 'Business, Management and Accounting' or ' Economics, Econometrics and Finance' were gathered from Scopus (period of reference 30 December 2010).

one (2005-10), the weight of descriptive science and technology and policy-oriented articles decreased about 16 and 3 percentage points, respectively. In contrast, papers related with descriptive science-industry/technology transfer registered a remarkable increase: from a meagre share of $2.6 \%$ in the $1995-99$ period, it reached $20.1 \%$ 10 years later (2005-10). Such an evolution can be explained by the huge scientific and political interest in university-firm relations (Grimaldi et al., 2011) and open innovation issues (Wang et al., 2012). Historical accounts also showed substantial growth, from $5.3 \%$ in $1995-99$ to around $19 \%$ in the most recent period. Historical accounts in the line of Freeman lie at the heart of the question that catch-up theories within the evolutionary school of economics sought to address (Reid and Ramani, 2012). The decrease in descriptive science and technology and policy-oriented articles and the increase in detailed historical accounts of NSI surpass to a certain extent NSI criticisms, most notably the argument that applications of the NIS approach are too static, descriptive and mechanical, focussing disproportionately on science and technology (Dodgson et al., 2011). Freeman-type historical accounts tend in contrast to emphasise the dynamic, emergent and evolving nature of systems and the multiple and distributed sources of knowledge for innovation (Lundvall, 2007).

Such a distribution of topics seems to be in line with the account provided by Balzat and Hanusch (2004), who highlighted that until the end of the 1990s historically detailed descriptions on NSI similar to Freeman's (albeit with a growing tendency) were rare and on demand, and noted the apparent scarcity of works using more formal and diversified quantitative methodologies for assessing the performance of NSI. Thus, the quest for more historical accounts seems to have echoed but the formal articles are weakly represented and show a declining trend after 1995 (see Figure 3). Indeed, the weight of studies on NSI that convey relations of causality between NSI agents and institutions, 


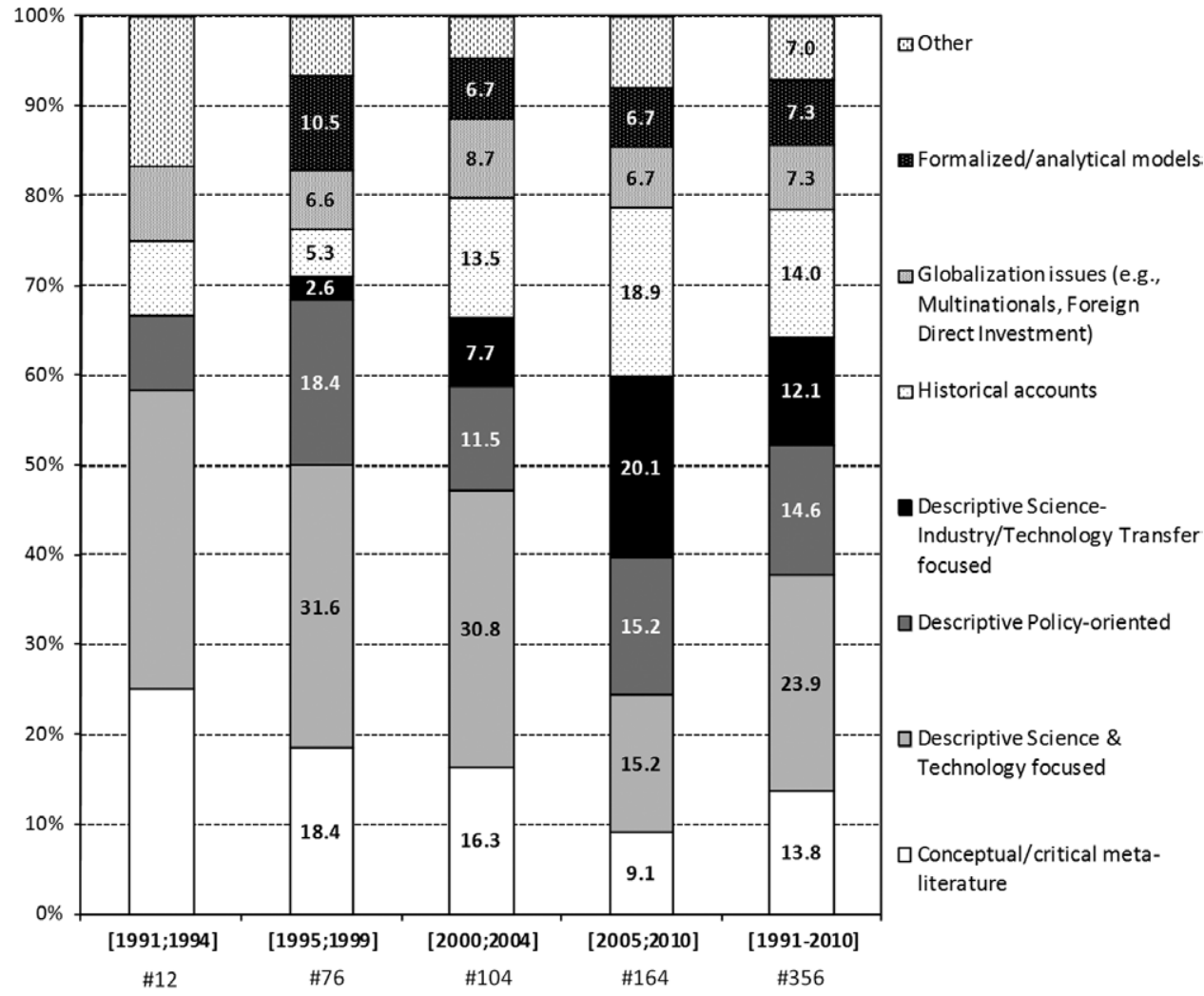

Fig. 2. NSI-related journal articles published by theme.

Note: The 328 articles were obtained from the Econlit and Scopus bibliographic databases using National System of Innovation and its variations as search keywords (the search was limited to journal articles).

resorting to analytical and formalised models and methods, represented about $10 \%$ of published articles at the end of 1990s and have decreased since then to about $6 \%$.

Most of the articles published on NSI (96\%) are empirical and appreciative (or a combination of these two types). In particular, NSI literature in the past 20 years has become increasingly empirically grounded.;

Despite the pressing need for comparative studies on countries' NSI (Edquist, 1997, 2005; Lundvall, 2007), the bulk of the studies focus on a single country (51\% for the 1991-2010 period; see Figure S1 in the supplementary material). Notwithstanding, studies involving more than one country, which represent around $15 \%$ of total articles in the 1995-99 period, saw their weight almost double in the more recent periods. The growing trend of single country studies might be considered a good sign for this field of research. In fact, to perform the sought-after rigorous, historical and systemic analysis of countries' NSI, a substantial amount of detailed and (often) idiosyncratic statistical and qualitative information is required. Thus, in a first stage, single-country analyses are likely to be advisable. Afterwards, as evidence on single countries emerges, we should expect richer comparative crosscountry analyses. 


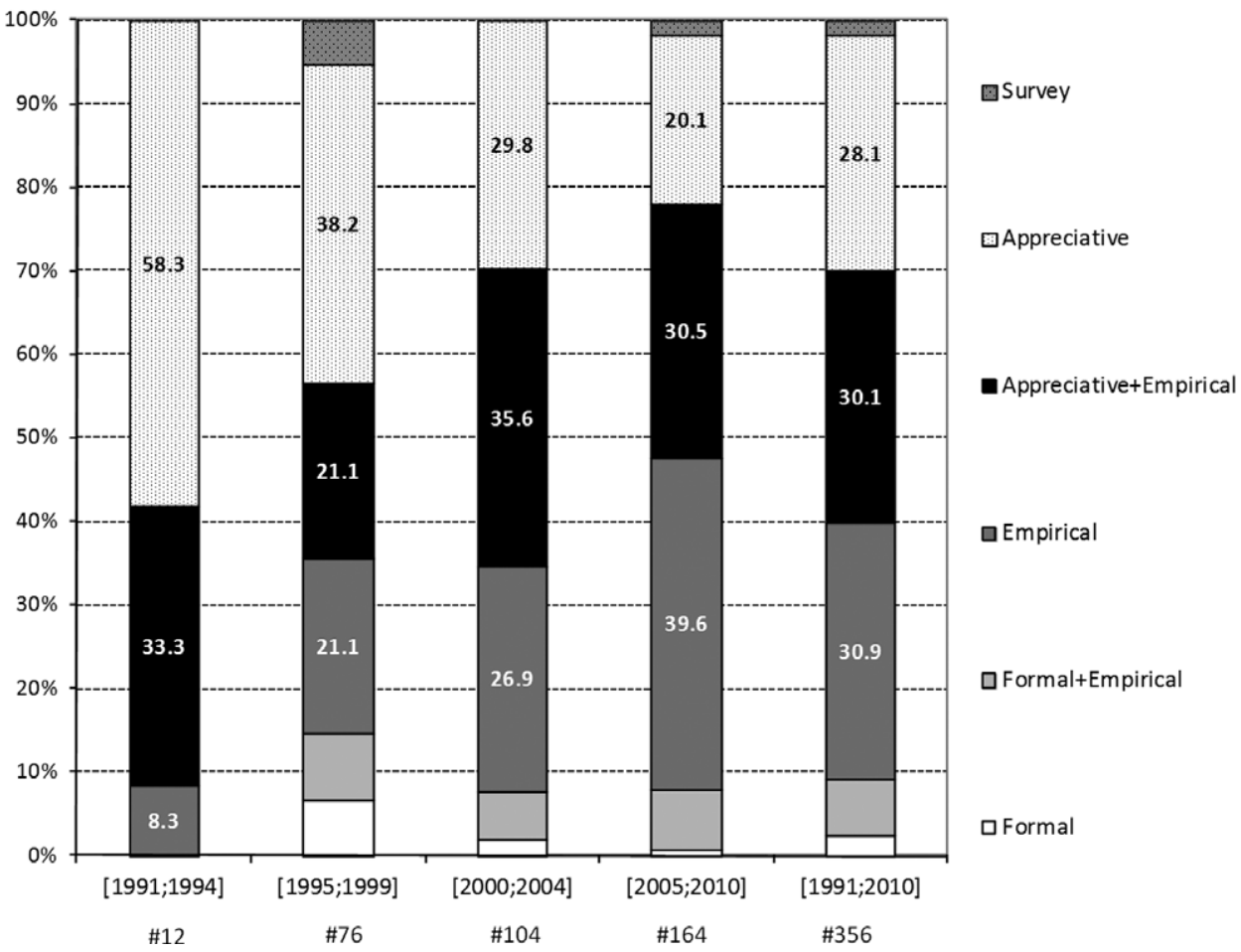

Fig. 3. Fournal articles published on NSI by type, 1991-2010.

Note: The 356 articles were obtained from the Econlit and Scopus bibliographic databases using National System of Innovation and its variations as search keywords (the search was unrestricted but limited to journal articles).

Among the (276) articles that explicitly analyzed or compared countries, $12.1 \%$ focussed on the United States and 9.5\% on China (Figure 4). The set of (25) countries depicted in Figure 4 represent almost $90 \%$ of the total references to countries, with the first five countries - the United States, China, Japan, Germany and Franceaccounting for $42 \%$ of the total references. It is interesting to note that a reasonably vast geographical area of the world has not yet been studied, most notably Africa and the Middle East. Given that in general these areas include some of the poorest and less developed countries in the world, this may indicate, as some argue (Albuquerque, 2007; Godin, 2009; Lorentzen, 2009), that the NSI framework is not suitable for studying such countries and/or areas. As Lorentzen (2009) underscores, experiences from other (less developed) countries are of great usefulness, contributing to the quest for policy diversity and customisation to adequately address the idiosyncrasies of countries.

Over the period in analysis, China together with other well-known Asian countries (Japan, South Korea and Taiwan) have had the most marked increase in studies focussing on their NSI (see Figure S2 in the supplementary material).

NSI research is significantly spread out among different outlets (Figure 5). The 356 articles were published in 129 journals, where the most important in terms of number of NSI articles published are Research Policy, with almost $13 \%$ of the total published articles, and Science and Public Policy and Technology in Society with 9\% and 6\% of the 


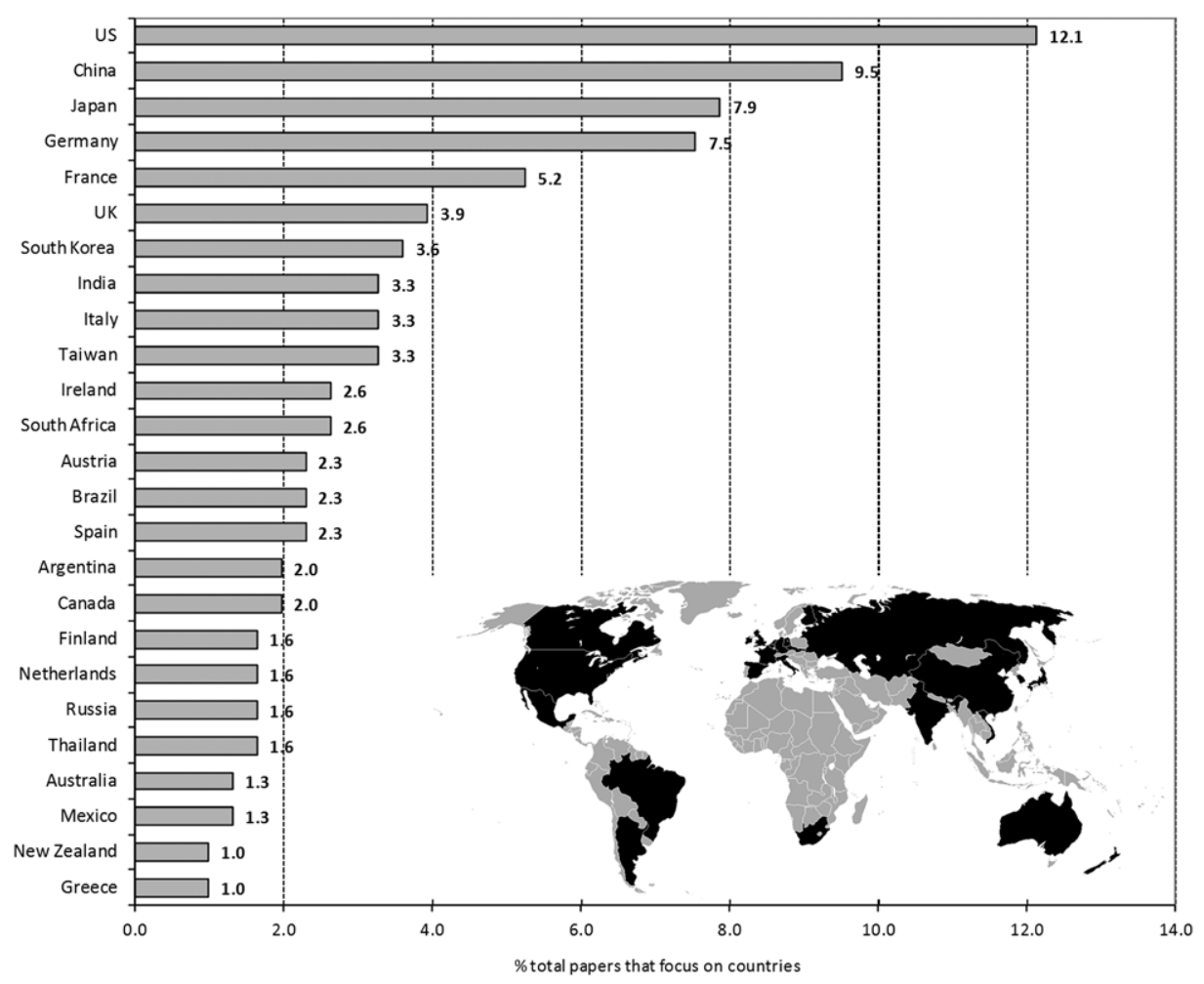

Fig. 4. Fournal articles published on NSI by country, 1991-2010.

Notes: A total of 53 distinct countries and 19 sets of countries were cited in the (251) journal articles analysed that focus countries or block of countries. The countries depicted represent $94 \%$

of the total (indicated in black in the map). Source of the map: http://www.mapsofworld.com.

total published articles, respectively. Regarding 'core' economics-related journals, the Cambridge fournal of Economics emerges (as exquo with another five journals, most notably, Industrial and Corporate Change) as the most important outlet, with $1.4 \%$ of the total NSI published journal articles.

It should be noted that Research Policy was launched at Freeman's research institute, Science and Technology Policy Research (SPRU), ${ }^{5}$ and Freeman himself was its founding editor. This providential coincidence does to a large extent reflect the existence of the so-called epistemic communities in this field of research (E. B. Haas, 1990; P. M. Haas, 1992; Adler and Haas, 1992).

Although, as could be expected, none of the mainstream journals appear amongst those mentioned in NSI-related research, there are important and renowned journals publishing in this area (beside Research Policy and Cambridge Fournal of Economics), namely, Industrial and Corporate Change and Regional Studies. The top 33 journals depicted are generally considered heterodox, because the bulk of their articles are

\footnotetext{
${ }^{5}$ Freeman was in fact the founder of SPRU, whose offices are today located in the Freeman Centre at the University of Sussex (UK).
} 


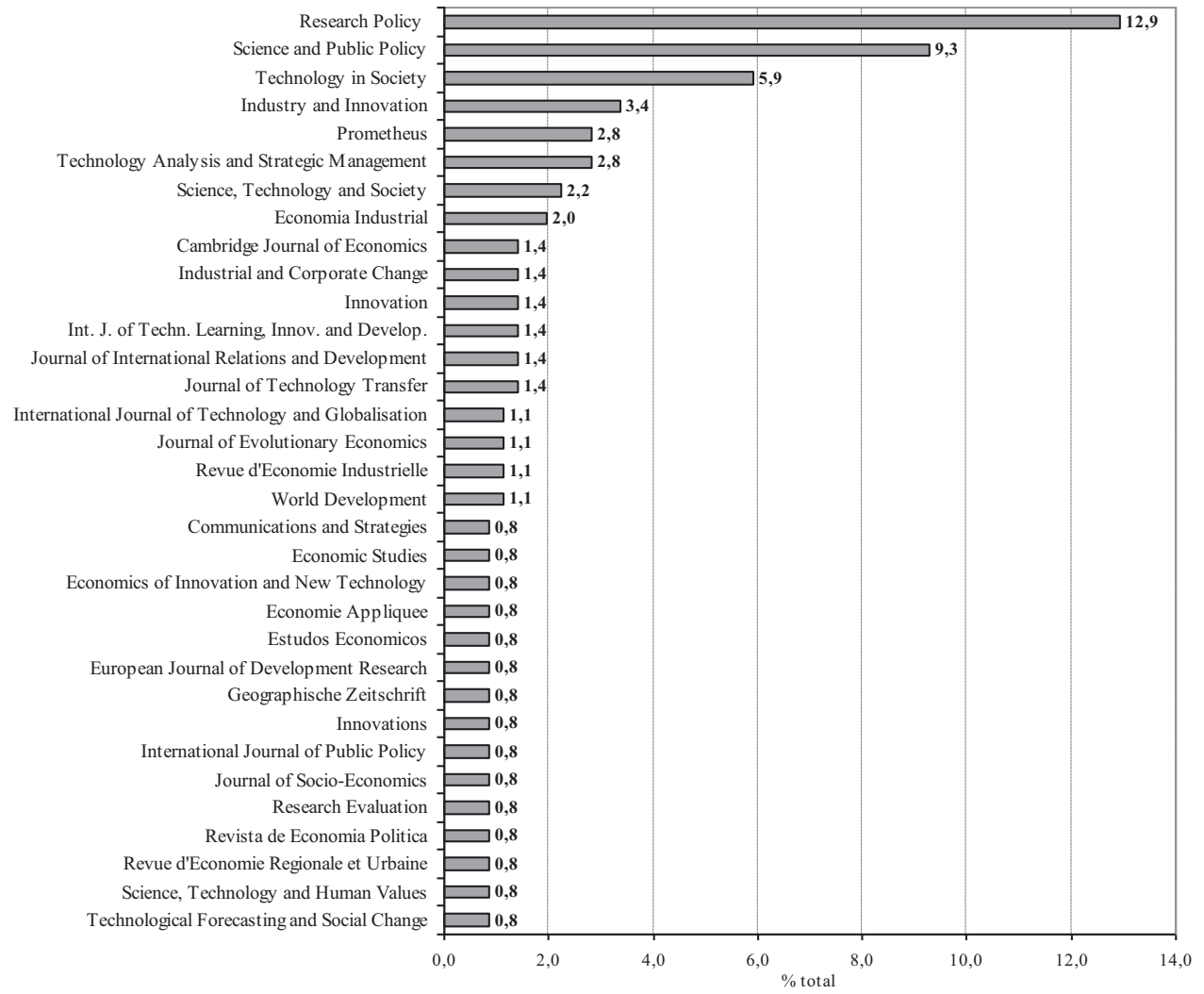

Fig. 5. Fournal articles published on NSI by journal, 1991-2010.

Note: The 356 articles were published in 129 distinct journals; the top 33 journals depicted here represent $67 \%$ of total articles.

often very critical of mainstream economics (Silva and Teixeira, 2009). This further stresses the fact the conceptual roots of NSI go deep into evolutionary economics. ${ }^{6}$

The organisations that are the building blocks of the NSI approach/concept-SPRU and Aalborg University-stand at the forefront in terms of the percentage of references to the authors' affiliation associated with the published articles (see Figure S3 in the supplementary material). The Fraunhofer Institute, SPRU and Aalborg have long-standing co-operation relations in innovation areas, a feature that further underpins the argument for the existence of epistemic communities in this area of research. It is interesting to note that some universities from South America (e.g., Universidade Federal de Minas Gerais, Brazil) and Asia (e.g., Seoul University, South Korea) are

${ }^{6}$ It is, nevertheless, rather puzzlingly the small weight that the Schumpeterian fournal of Evolutionary Economics has in the development of the literature on the NSI (presenting only $1.1 \%$ of the total articles published). This might be explained partly by the lack of agreement by evolutionary economists on the 'core' evolutionary principles and topics. Silva's (2009) account about the six families included in the 'tribe' of evolutionary technological change and economic growth (innovation systems literature; historian approach; sectoral patterns of technical change; technological gap literature; lock-in models; evolutionary growth models) insightfully describes that within the 'evolutionary tribe' what separates the families is much greater than what unites them. 


\section{Page 14 of 34 A. A. C. Teixeira}

quite active in this field. The importance of these organisations reflects the emergence of a new field within NSI-related research, the developing/transition studies on NSI (Asakawa and Som, 2008; Guennif and Ramani, 2012; Reid and Ramani, 2012). The papers on NSI by Asian-affiliated authors observed a huge increase from the early 2000 s to the end of the period of analysis (2005-10) of 12 percentage points. This contrasts with the downward trend observed for the European block (see Figure S4 in the supplementary material).

\subsection{The scientific roots of the NSI literature}

From the 356 articles published on NSI, I managed to download and gather the references of 297 articles (83.4\% of the total). From each downloaded article I copied and pasted their references (citations) and re-formatted them to be able to treat them quantitatively. ${ }^{7}$

The 297 articles yielded more than 13,000 citations (more precisely 13,556), with over 4,037-that is, a third of the articles-published in journals. In total, 7,093 distinct authors were cited.

The bulk of the citations refer to studies published between 1993 and 2002, reaching a peak for studies published in 1997 (see Figure S5 in the supplementary material).

The most widely cited authors are Richard Nelson, Bengt-Åke Lundvall and Chris Freeman, the founding fathers of the NSI approach (see Table 2). Among the top 10 most influential authors, three are or were mainly affiliated with SPRU (University of Sussex), which has been a true incubator of leading authors in innovation studies over the past few decades. Beside these three authors, about one third of the authors listed obtained their doctorate at SPRU (e.g., Carlota Perez, Daniele Archibugi, Giovanni Dosi, Jan Fagerberg, Luc Soete, Luigi Orsenigo) and/or were visiting researchers who maintain very close research ties with its members (e.g., Bengt-Åke Lundvall, David Mowery, Nathan Rosenberg, Richard Nelson). One might state that most of the top cited authors in the NSI literature form a close network of interlinked researchers who constitute an elite 'visible college' (Teixeira, 2011).

It is interesting to note that the top cited authors by NSI articles are also quite widely cited by studies in general, most notably from those in innovation, as the figures (total citations) in the square brackets in Table 3 indicate - for instance, Richard Nelson (Columbia University, United States) is, among the top authors listed, simultaneously the most cited by NSI articles and the most cited by studies published in sources indexed in Scopus.

Although the articles published on NSI (from 1991 to 2010) cite a large number of studies - precisely 8,383 distinct studies - each receives a small number of citations. Indeed, only 30 studies $(0.4 \%$ of the total) received 15 or more citations from the NSI literature (see Table 4). Of these 30 studies, the vast majority are books (14), book chapters (4), or OECD reports (2). It is interesting to note that the four book chapters listed in top 30 are included in the book Technical Change and Economic Theory, edited by Dosi, Freeman, Nelson, Silverberg and Soete (1988), which resulted from the landmark International Federation of Institutes for Advanced Study project (Sharif, 2006). The two major roots for NSI literature, which received more than 100 citations, are also edited volumes: National

\footnotetext{
${ }^{7}$ Although for more recent articles SciVerse Scopus automatically provides the references cited in each published article, I accomplished both procedures (the automatic and the manual one) and found large differences, with the automatic one missing hundreds of references. I did not look further into the reasons for the differences, and I opted for the more time-consuming but more rigorous manual process. Additionally, as some articles/journals at the time of their publication were not indexed in the bibliographic database, the automatic procedure was not useful.
} 
Table 2. The top 30 most cited authors by the NSI literature (ordered by number of citations)

\begin{tabular}{|c|c|c|c|c|}
\hline Rank & Author & Affiliation ${ }^{\star}$ & $\begin{array}{l}\text { Number of citations } \\
\text { by NSI articles }\end{array}$ & $\begin{array}{l}\text { Total citations in } \\
\text { Scopus }\end{array}$ \\
\hline 1 & Nelson, Richard & $\begin{array}{l}\text { Columbia } \\
\text { University (US) }\end{array}$ & 487 & 3,014 \\
\hline 2 & Lundvall, Bengt-Åke & $\begin{array}{l}\text { Aalborg University } \\
\text { (Denmark) }\end{array}$ & 407 & 400 \\
\hline 3 & Freeman, Chris ${ }^{\dagger}$ & $\begin{array}{l}\text { SPRU, University } \\
\text { of Sussex (UK) }\end{array}$ & 347 & 1,086 \\
\hline 4 & Pavitt, Keith ${ }^{\dagger}$ & $\begin{array}{l}\text { SPRU, University } \\
\text { of Sussex (UK) }\end{array}$ & 214 & 2,486 \\
\hline 5 & Rosenberg, Nathan & $\begin{array}{l}\text { Stanford } \\
\text { University (US) }\end{array}$ & 168 & 938 \\
\hline 6 & Mowery, David & $\begin{array}{l}\text { University of } \\
\text { California at } \\
\text { Berkeley (US) }\end{array}$ & 145 & 2,036 \\
\hline 7 & Dosi, Giovanni & $\begin{array}{l}\text { Scuola Superiore } \\
\text { Sant'Anna di Studi } \\
\text { Universitari e di } \\
\text { Perfezionamento } \\
\text { (Italy) }\end{array}$ & 137 & 2,256 \\
\hline 8 & Edquist, Charles & $\begin{array}{l}\text { Lund University } \\
\text { (Sweden) }\end{array}$ & 132 & 81 \\
\hline 9 & Patel, Pari & $\begin{array}{r}\text { SPRU, University } \\
\text { of Sussex (UK) }\end{array}$ & 112 & 685 \\
\hline 10 & Porter, Michael & $\begin{array}{l}\text { Harvard } \\
\text { University (US) }\end{array}$ & 110 & 4,223 \\
\hline 11 & Soete, Luc & $\begin{array}{l}\text { UNU-Merit, } \\
\text { United Nations } \\
\text { University (The } \\
\text { Netherlands) }\end{array}$ & 96 & 423 \\
\hline 12 & Malerba, Franco & $\begin{array}{l}\text { Bocconi Universiy } \\
\text { (Italy) }\end{array}$ & 93 & 1,159 \\
\hline 13 & Johnson, Bjørn & $\begin{array}{l}\text { Aalborg University } \\
\text { (Denmark) }\end{array}$ & 92 & 367 \\
\hline 14 & Winter, Sidney & $\begin{array}{l}\text { University of } \\
\text { Pennsylvania (US) }\end{array}$ & 91 & 2,995 \\
\hline 15 & Cooke, Philip & Cardiff University (UK) & 85 & 1,648 \\
\hline 16 & Carlsson, Bo & $\begin{array}{c}\text { Case Western Reserve } \\
\text { University (US) }\end{array}$ & 78 & 782 \\
\hline 17 & Archibugi, Daniele & $\begin{array}{l}\text { Italian National } \\
\text { Research } \\
\text { Council (Italy) }\end{array}$ & 73 & 675 \\
\hline 18 & David, Paul & $\begin{array}{l}\text { Stanford } \\
\quad \text { University (US) }\end{array}$ & 72 & 1,160 \\
\hline 19 & Etzkowitz, Henry & $\begin{array}{l}\text { Newcastle } \\
\text { University (UK) }\end{array}$ & 70 & 1,664 \\
\hline 20 & Cohen, Wesley & Duke University (US) & 67 & 875 \\
\hline 21 & Andersen, Esben S. & $\begin{array}{l}\text { Aalborg University } \\
\text { (Denmark) }\end{array}$ & 60 & 188 \\
\hline 22 & Foray, David & $\begin{array}{l}\text { École Polytechnique } \\
\text { Fédérale de Lausanne } \\
\text { (Switzerland) }\end{array}$ & $e^{59}$ & 271 \\
\hline 23 & Schumpeter, Joseph ${ }^{\dagger}$ & $\begin{array}{l}\text { Harvard University } \\
\text { (US) }\end{array}$ & 59 & - \\
\hline
\end{tabular}


Page 16 of 34 A. A. C. Teixeira

Table 2. Continued

\begin{tabular}{|c|c|c|c|c|}
\hline Rank & Author & Affiliation ${ }^{\star}$ & $\begin{array}{l}\text { Number of citations } \\
\text { by NSI articles }\end{array}$ & $\begin{array}{l}\text { Total citations in } \\
\text { Scopus } \star \star\end{array}$ \\
\hline$\overline{24}$ & Kim, Linsu ${ }^{\dagger}$ & $\begin{array}{l}\text { Korea University } \\
\text { (South Korea) }\end{array}$ & 58 & 574 \\
\hline 25 & Leydesdorff, Loet & $\begin{array}{l}\text { University of } \\
\text { Amsterdam (The } \\
\text { Netherlands) }\end{array}$ & 57 & 2,667 \\
\hline 26 & Metcalfe, Stan & $\begin{array}{l}\text { Manchester University } \\
\text { (UK) }\end{array}$ & 55 & 539 \\
\hline 27 & Levinthal, D. & $\begin{array}{l}\text { University of } \\
\text { Pennsylvania (US) }\end{array}$ & 49 & 1,637 \\
\hline 28 & Cantwell, John & $\begin{array}{l}\text { Rutgers University } \\
\text { (US) }\end{array}$ & 48 & 559 \\
\hline 29 & Fagerberg, Jan & $\begin{array}{l}\text { University of Oslo } \\
\text { (Norway) }\end{array}$ & 47 & 670 \\
\hline 30 & Perez, Carlota & $\begin{array}{l}\text { Tallinn University of } \\
\text { Technology (Estonia) }\end{array}$ & 46 & 211 \\
\hline \multirow[t]{2}{*}{31} & Orsenigo, Luigi & $\begin{array}{l}\text { Bocconi Universiy } \\
\text { (Italy) }\end{array}$ & 46 & 1,002 \\
\hline & Other authors & & $<46$ & \\
\hline
\end{tabular}

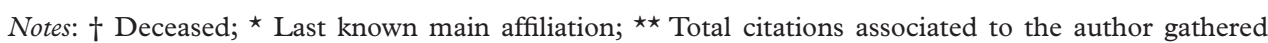
from Sci Verse Scopus database (reference date: December 2010). The database includes 13,556 citations to 8,383 distinct studies, authored or co-authored by 7,093 different authors, made by the 297 journal articles published on NSI. The citations were taken manually from the references of each of the 297 journal articles ( $83.4 \%$ of the total) that were available at the Scopus/ISI/Econlit/Google. The bulk (around $68 \%$ ) of authors have only one citation. Twenty percent of total citations are made to a meagre group of ( 31 or $0.5 \%$ of total) authors, who have 45 or more citations.

Systems of Innovation: Towards a Theory of Innovation and Interactive Learning (organized by Bengt-Åke Lundvall) and National Innovation Systems: A Comparative Analysis (Nelson, 1993) - that were published in the early 1990s.

The book by Freeman (1987) on Japan is considered by some to be the first study that introduced the concept of NSI in academic circles (Sornn-Friese, 2000; Lundvall, 2004), even though Lundvall had in fact used the concept 'Innovation Systems' in his 1985 study, "Product Innovation and User Producer Interaction" (also included in Table 4 as one of the main roots of NSI literature), but without the adjective 'national' attached to it. Freeman's book can nevertheless be considered the first widely published use of the concept (Sharif, 2006; Lundvall, 2007), when he connected NSI to his analysis of the institutional reasons for the 'developmental gap', that is, differences in the rates of economic growth amongst nations. It is important to mention that the first use of the NSI terminology in written form occurred outside the academic world, in the politics sphere, by Freeman in 'Technological Infrastructure and International Competitiveness', which he presented in August 1982 at the OECD's expert group on Science, Technology and Competitiveness, but which remained unpublished at the time (Freeman, 1995; Carlsson, 2006). ${ }^{8}$

Of the few articles among the top 30 studies from the NSI literature, the most cited (among the articles) is by Freeman ("The National System of Innovation in Historical

\footnotetext{
8 This paper was published in 2004 (Freeman, 2004), with a foreword by Lundvall (Lundvall, 2004), 22 years after it had been presented originally.
} 


\section{Bibliometric account of NSI Page 17 of 34}

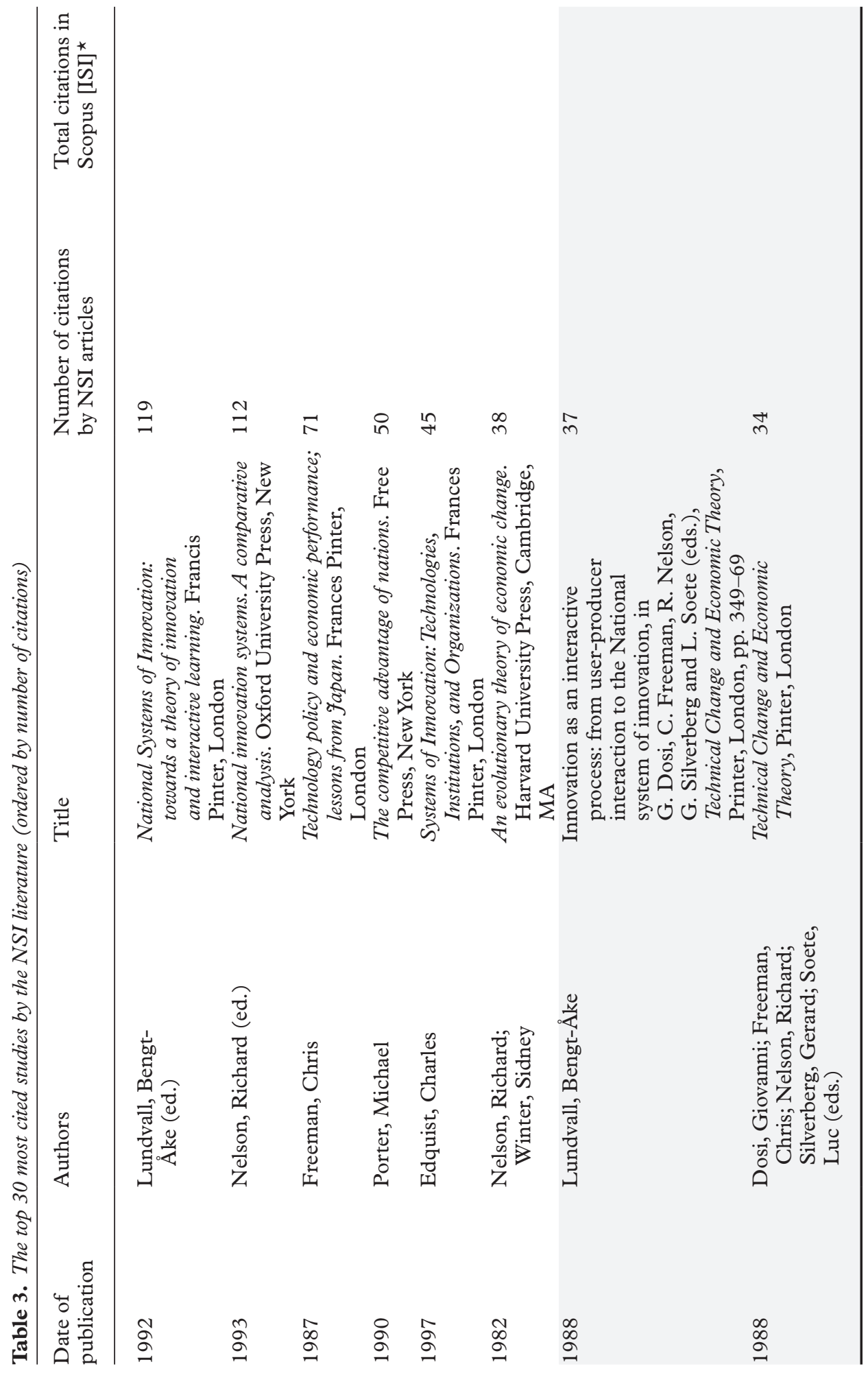




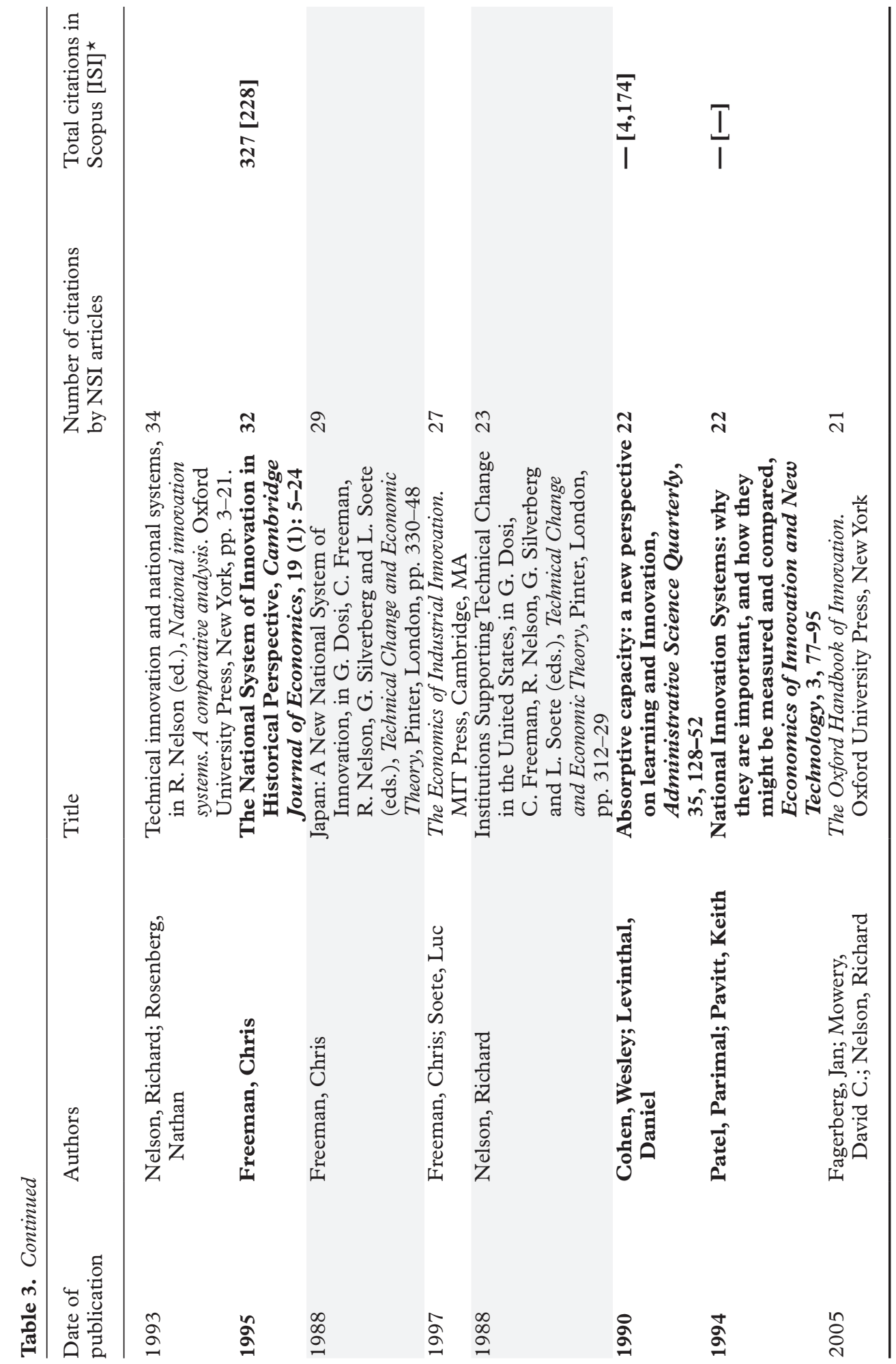


Bibliometric account of NSI Page 19 of 34

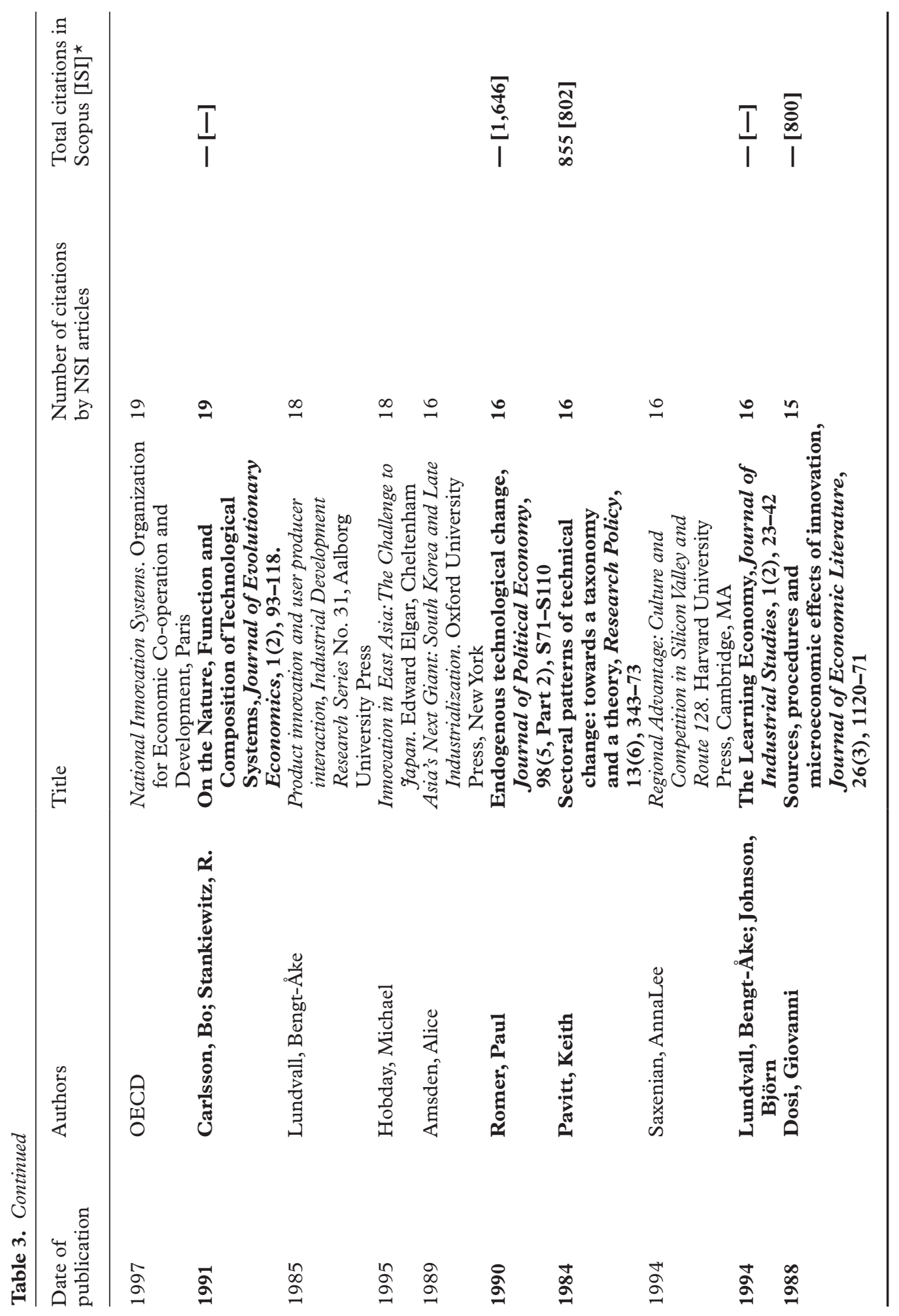


Page 20 of 34 A. A. C. Teixeira

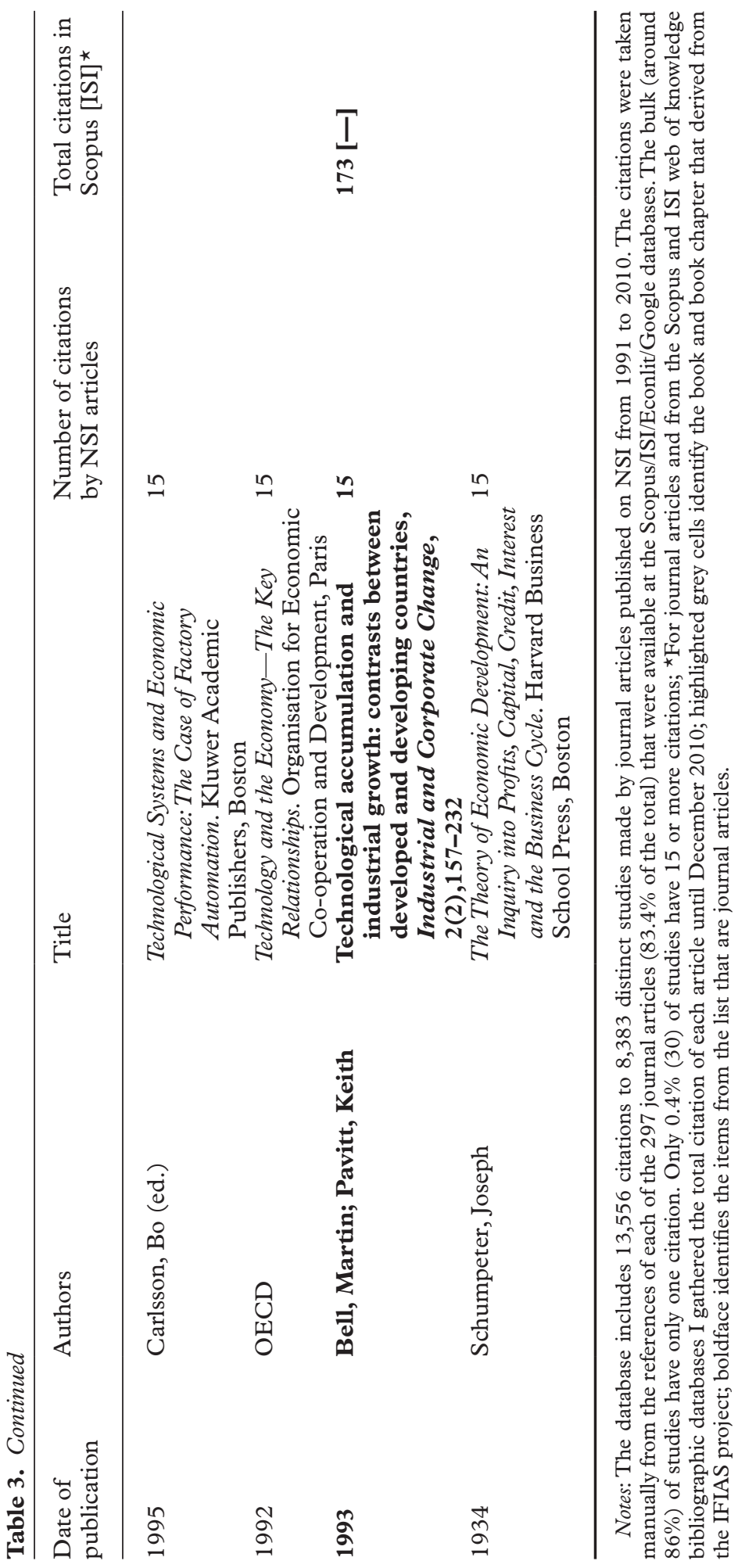


Perspective") in the Cambridge fournal of Economics (1995). Although this article received a relatively low number of citations by NSI articles published between 1991 and 2010, it is a seminal paper in innovation studies, which received, until December 2010, 327 citations from sources indexed in Scopus and 228 citations from the ISI Web of Knowledge.

In line with Freeman's article, most of the studies listed among the top 30 cited by the NSI literature lie at the core of NSI and innovation studies. The exceptions, although related with innovation issues, appeared in the managerial field and include the book by Michael Porter, The Competitive Advantage of Nations, and the groundbreaking article by Wesley Cohen and Daniel Levinthal, "Absorptive Capacity: A New Perspective on Learning and Innovation" (published in Administrative Science Quarterly), which received, until December 2010, over 4,000 citations (from the ISI Web of Knowledge database).

Based on top cited studies and authors, I could state that the roots of the NSI literature lie squarely within innovation studies. A distinct picture, however, emerges when we take into account the citations of journals and their corresponding scientific area. ${ }^{9}$ NSI-related articles tend to cite studies published in high-impact factor journals from three main areas, business and management, regional subject areas (environmental studies, geography, planning and development and urban studies), and economics. About a third (33.6\%) of the total journal citations are made to outlets from the business and management fields, particularly to Research Policy, the most cited journal by NSI literature with $16.8 \%$ of the total citations (see Figure 6 ). The economics and regional fields of research are also an important scientific source of NSI literature, accounting for $20.7 \%$ and $24.0 \%$ of the total citations, respectively. The

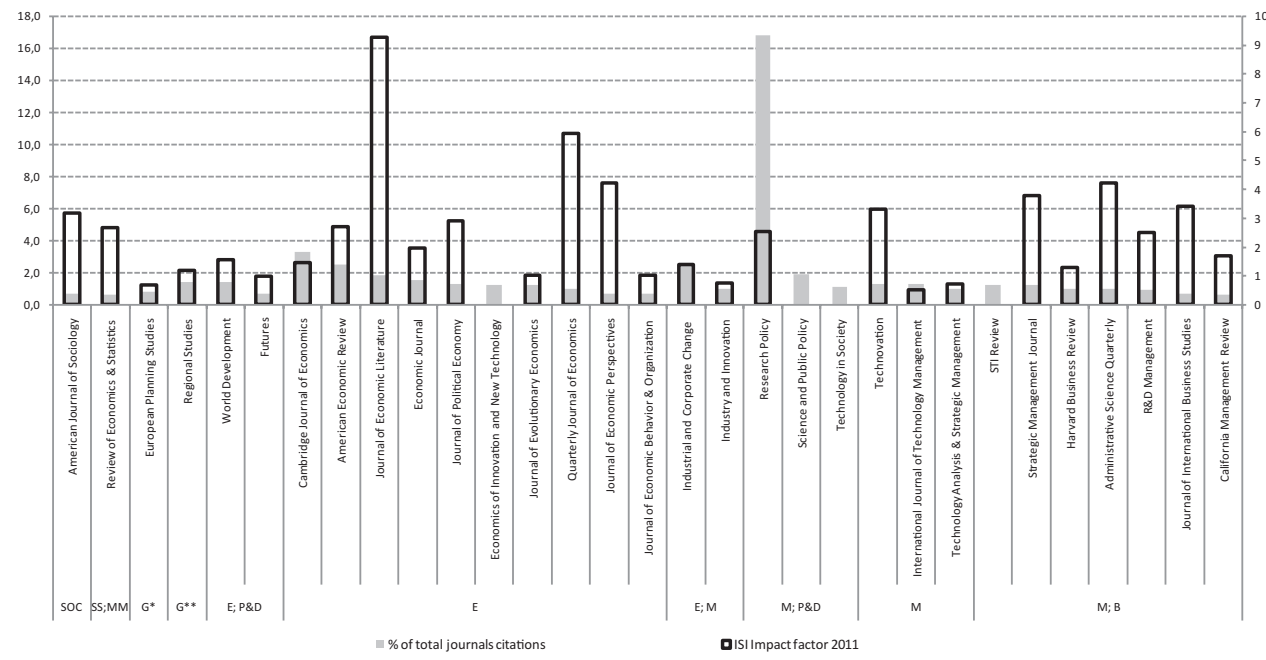

Fig. 6. Citations made by the articles published (1991-2010) on NSI by journal citedLegend: B: Business; E: Economics; ES: Environmental Studies; M: Management; MM: Mathematical Methods; PEDD: Planning $\mathcal{E}$ Development; SS: Social Sciences; SOC: Sociology; $G^{\star}$ : includes ES; Geography; PE्DD; Urban Studies; ${ }^{\star *}$ : includes ES; Geography.

Notes: Data cover 13,556 citations made by 297 articles on NSI published between 1991 and 2010; top 30 most cited journals represent $4.2 \%$ of the journals cited and $54.2 \%$ of the total citations.

${ }^{9}$ The scientific area considered here was the 'subject categories', in which ISIThompson classifies indexed journals. The four journals (Economics of Innovation and New Technology, Science and Public Policy, STI Review, Technology in Society) that were not indexed in ISI were classified based on their scope. 


\section{Page 22 of 34 A. A. C. Teixeira}

most important source in terms of outlet within economics is the Cambridge fournal of Economics, accounting for $3.3 \%$ of total journal citations.

This analysis highlights a clear pattern in the scientific roots of the NSI literatureits multi-disciplinary traits are a fertile and rich crossroads of concepts, analytical frameworks and methods from the management and business, regional science and economics fields of research.

\subsection{The scientific influence of the NSI literature}

From the 356 articles published on NSI from 1991 to $2010,53.4 \%$ were cited at least once by other studies (dealing or not with NSI issues). ${ }^{10} \mathrm{~A}$ small number of articles (25, that is, $7 \%$ of the total) might be considered 'seminal' in the sense that they were cited, by the end of December 2010, 30 times or more by other studies. ${ }^{11}$

Most of the 25 seminal articles (see Table 4) are conceptual $(36 \%)$ or descriptive with a science and technology focus $(24 \%)$. Around $48 \%$ of the seminal NSI papers have no country focus, whereas a similar number focussed on individual country (seven papers, 28\%) or comparative country (six papers, $24 \%$ ) analyses. The seminal NSI articles were mainly published by 1995 (16\%) and by 2002 (28\%). Of the 13 articles that focus (individually or comparatively) on countries' experiences, in $6(46 \%)$ of them one of the countries in analysis is the United States, and in 4 (31\%) the country studied is Germany. Exactly $60 \%$ of the seminal NSI papers (15) were published in Research Policy. The Cambridge fournal of Economics follows with four seminal articles ( $16 \%$ of the total).

The 'influence' database was built based on the number of citations to the seminal NSI articles. I gathered 2,109 studies (mostly journal articles). The papers that cite NSI seminal papers total 2,344 distinct authors and co-authors, 1,820 (88\%) of whom are affiliated in 702 distinct organizations located in 56 different countries. ${ }^{12}$

It is interesting to note that the authors that cite the seminal NSI papers are affiliated in organisations located mostly in Europe (48.0\%), most notably in the United Kingdom (14.5\%), the Netherlands (9.7\%), Germany (7.9\%), Italy $(6.0 \%)$, Spain $(5.1 \%)$ and Sweden (5.0\%). Outside Europe, the United States $(11.0 \%)$ emerges as a key citation outlet for NSI seminal papers. Based on the map drawn in Figure 7, which depicts the number (and percentage) of authors citing NSI seminal articles by the geographical location of their affiliation, I conclude that the influence of NSI literature (measured by the citations to NSI seminal articles) is quite widespread geographically, encompassing almost 60 countries all over the world.

It is possible also to infer that the influence of NSI seminal literature in countries such as Sweden, the Netherlands and, to a lesser extent, Germany and Spain, is quite concentrated around some key organisations (Table 5). For instance, in the Netherlands and Sweden, around 55\% and $80 \%$, respectively, of the total citations to NSI seminal papers were made by authors affiliated with the universities of Utrecht,

${ }^{10}$ The period of reference for this data gathering from Scopus and the ISI bibliographic databases is 31 December 2010.

${ }^{11}$ The vast majority (over 90\%) of these studies is journal articles; the remaining are review or conference articles. See Figure S6 in the supplementary material.

${ }^{12}$ For around $12 \%$ of the authors who cite NSI seminal papers, the affiliation information was not available in Scopus database. For those who have this information, the affiliation considered was the first one indicated by the authors. 
Table 4. Seminal NSI articles

\begin{tabular}{|c|c|c|c|}
\hline Year & Title (authors) & Journal & $\begin{array}{l}\text { Number of citations } \\
\text { in Scopus }\end{array}$ \\
\hline 2000 & $\begin{array}{l}\text { The dynamics of innovation: } \\
\text { from National Systems } \\
\text { and 'mode 2' to a Triple } \\
\text { Helix of university- } \\
\text { industry-government } \\
\text { relations (Etzkowitz, H.; } \\
\text { Leydesdorff, L.) }\end{array}$ & Research Policy & 483 \\
\hline 1995 & $\begin{array}{l}\text { The 'National System of } \\
\text { Innovation' in historical } \\
\text { perspective (Freeman, C.) }\end{array}$ & $\begin{array}{l}\text { Cambridge fournal of } \\
\text { Economics }\end{array}$ & 327 \\
\hline 1991 & $\begin{array}{l}\text { Networks of innovators: a } \\
\text { synthesis of research issues } \\
\text { (Freeman, C.) }\end{array}$ & Research Policy & 314 \\
\hline 1991 & $\begin{array}{l}\text { On the nature, function and } \\
\text { composition of technological } \\
\text { systems (Carlsson, B.; } \\
\text { Stankiewicz, R.) }\end{array}$ & $\begin{array}{l}\text { Fournal of Evolutionary } \\
\text { Economics }\end{array}$ & 211 \\
\hline 2002 & $\begin{array}{l}\text { National Systems of } \\
\text { Production, innovation } \\
\text { and competence building } \\
\text { (Lundvall, B.-A.; Johnson, B.; } \\
\text { Andersen, E.S.; Dalum, B.) }\end{array}$ & Research Policy & 165 \\
\hline 1998 & $\begin{array}{l}\text { Science-based technologies: } \\
\text { University-Industry } \\
\text { interactions in four fields } \\
\text { (Meyer-Krahmer, F.; } \\
\text { Schmoch, U.) }\end{array}$ & Research Policy & 154 \\
\hline 1995 & $\begin{array}{l}\text { The globalisation of technology: } \\
\text { a new taxonomy (Archibugi, } \\
\text { D.; Michie, J.) }\end{array}$ & $\begin{array}{l}\text { Cambridge fournal of } \\
\text { Economics }\end{array}$ & 132 \\
\hline 2001 & $\begin{array}{l}\text { Business services as actors of } \\
\text { knowledge transformation: } \\
\text { the role of KIBS in Regional } \\
\text { and National Innovation } \\
\text { Systems (Muller, E.; } \\
\text { Zenker, A.) }\end{array}$ & Research Policy & 119 \\
\hline 1998 & $\begin{array}{l}\text { Regional Systems of Innovation: } \\
\text { an evolutionary perspective } \\
\text { (Cooke, P.; Uranga, M.G.; }\end{array}$ & $\begin{array}{l}\text { Environment and Planning } \\
\quad A\end{array}$ & 87 \\
\hline
\end{tabular}
Etxebarria, G.) to China's transitional context (Liu, X.; White, S.) competitiveness: the role of Cambridge fournal of Economics National Innovation Systems (Mowery, D.C.; Oxley, J.E.) technology policy in an evolutionary framework (Metcalfe, J. S.) 
Page 24 of 34 A. A. C. Teixeira

Table 4. Continued

\begin{tabular}{|c|c|c|c|}
\hline Year & Title (authors) & Journal & $\begin{array}{l}\text { Number of citations } \\
\text { in Scopus }\end{array}$ \\
\hline 2002 & $\begin{array}{l}\text { Location versus home country } \\
\text { advantages' in R\&D activi- } \\
\text { ties: some further results on } \\
\text { Multinationals' locational strat- } \\
\text { egies (le Bas, C.; Sierra, C.) }\end{array}$ & Research Policy & 74 \\
\hline 2002 & $\begin{array}{l}\text { Continental, National and } \\
\text { Sub-national Innovation } \\
\text { Systems-complementa- } \\
\text { rity and economic growth } \\
\text { (Freeman, C.) }\end{array}$ & Research Policy & 61 \\
\hline 1993 & $\begin{array}{l}\text { National systems of innova- } \\
\text { tion: in search of a workable } \\
\text { concept (Niosi, J.; Saviotti, P.; } \\
\text { Bellon, B.; Crow, M.) }\end{array}$ & Technology in Society & 49 \\
\hline 2002 & $\begin{array}{l}\text { The evolution of technolo- } \\
\text { gies in time and space: from } \\
\text { National and Regional to } \\
\text { Spatial Innovation Systems } \\
\text { (Oinas, P.; Malecki, E.) }\end{array}$ & $\begin{array}{l}\text { International Regional } \\
\text { Science Review }\end{array}$ & $49^{\star}$ \\
\hline 2001 & $\begin{array}{l}\text { Why research partnerships } \\
\text { really matter: innovation } \\
\text { theory, institutional arrange- } \\
\text { ments and implications for } \\
\text { developing new technol- } \\
\text { ogy for the poor (Hall, A.; } \\
\text { Bockett, G.; Taylor, S.; } \\
\text { Sivamohan, M.V.K.; } \\
\text { Clark, N.) }\end{array}$ & World Development & 42 \\
\hline 2000 & $\begin{array}{l}\text { Systems of Innovation in tradi- } \\
\text { tional industrial regions: the } \\
\text { case of Styria in a compara- } \\
\text { tive perspective (Kaufmann, } \\
\text { A.; Todtling, F.) }\end{array}$ & Regional Studies & $41^{\star}$ \\
\hline 1998 & $\begin{array}{l}\text { The changing structure of the } \\
\text { US National Innovation } \\
\text { System: implications for } \\
\text { international conflict and } \\
\text { cooperation in R\&D policy } \\
\text { (Mowery, D.C.) }\end{array}$ & Research Policy & 39 \\
\hline 1999 & $\begin{array}{l}\text { Technological entry, exit and } \\
\text { survival: an empirical analysis } \\
\text { of patent data (Malerba, F.; } \\
\text { Orsenigo, L.) }\end{array}$ & Research Policy & 37 \\
\hline 2002 & $\begin{array}{l}\text { National Innovation System } \\
\text { in less successful develop- } \\
\text { ing countries: the case of } \\
\text { Thailand (Intarakumnerd, } \\
\text { P.; Chairatana, P.; } \\
\text { Tangchitpiboon, T.) }\end{array}$ & Research Policy & 37 \\
\hline 2006 & $\begin{array}{l}\text { Internationalization of } \\
\text { innovation systems: } \\
\text { a survey of the Literature } \\
\text { (Carlsson, B.) }\end{array}$ & Research Policy & 34 \\
\hline
\end{tabular}


Table 4. Continued

\begin{tabular}{|c|c|c|c|}
\hline Year & Title (authors) & Journal & $\begin{array}{l}\text { Number of citations } \\
\text { in Scopus }\end{array}$ \\
\hline 2000 & $\begin{array}{l}\text { Local systems of innovation in } \\
\text { a globalized world economy } \\
\text { (Mytelka, L.K.) }\end{array}$ & Industry and Innovation & 32 \\
\hline 2002 & $\begin{array}{l}\text { National Systems of } \\
\text { Innovations are 'X-efficient' } \\
\text { (and X-effective): why some } \\
\text { are slow learners (Niosi, J.) }\end{array}$ & Research Policy & 31 \\
\hline 2002 & $\begin{array}{l}\text { Is the Internet a US inven- } \\
\text { tion?-an economic and tech- } \\
\text { nological history of computer } \\
\text { networking (Mowery, D.C.; } \\
\text { Simcoe, T.) }\end{array}$ & Research Policy & 30 \\
\hline
\end{tabular}

Note: Based on the 356 articles that were published between 1991 and 2010 in journals indexed in Econlit and Scopus (limited to Social Sciences journal articles), I gathered their citations from Scopus (and ISI when citation in Scopus were not available, as in the case of ${ }^{\star}$ ) with reference date December 2010).

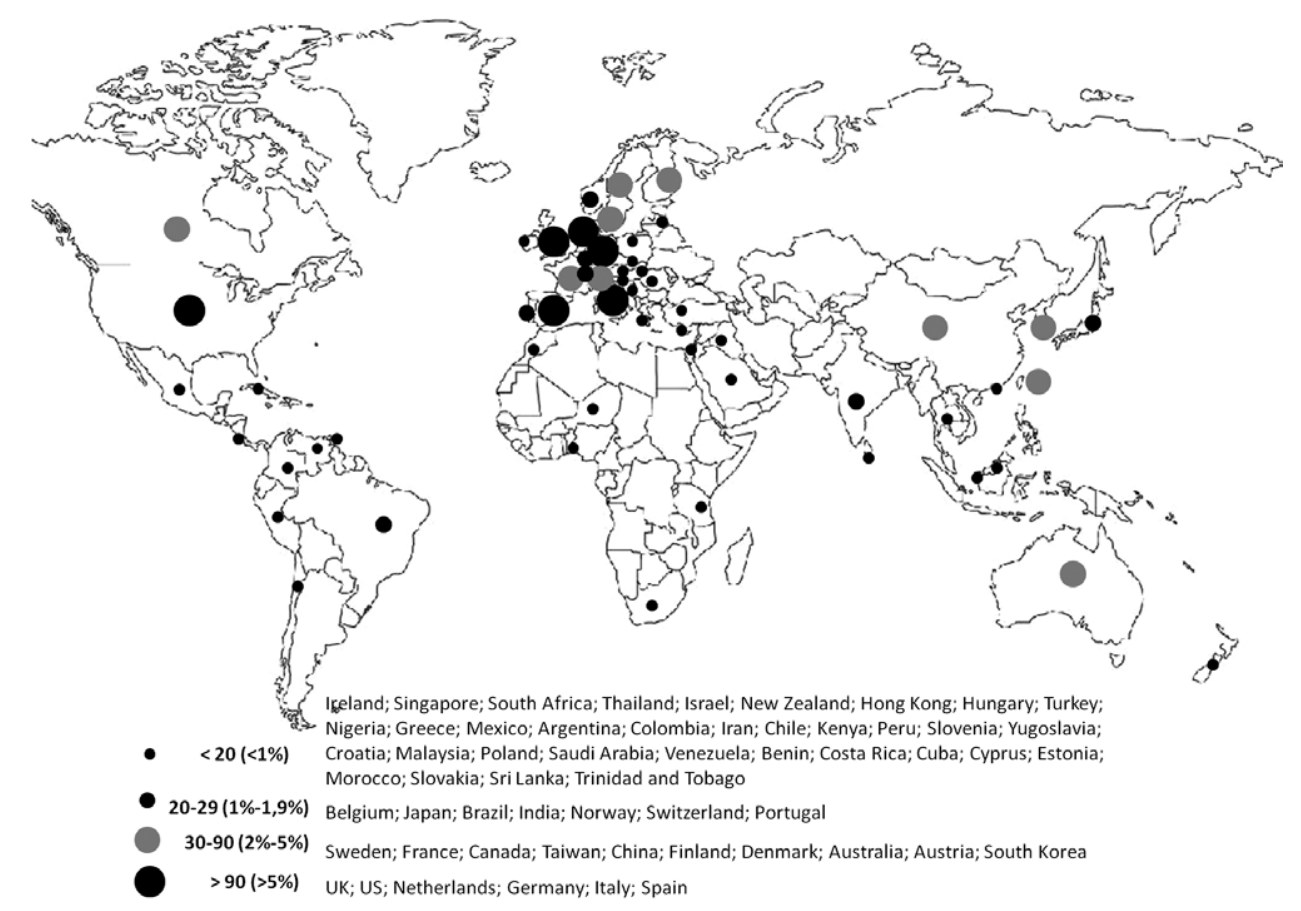

Fig. 7. Assessing the geographical influence of NSI seminal articles: number (\%) of authors citing NSI seminal articles by affiliation geographical location.

Notes: From the 2,062 articles citing the NSI seminal papers, I managed to obtain information on the affiliation of 1,820 corresponding authors. Then these 1,820 affiliations were treated to get the corresponding country, which enable to compute the geographical distribution of the papers citing NSI seminal papers. 
Page 26 of 34 A. A. C. Teixeira

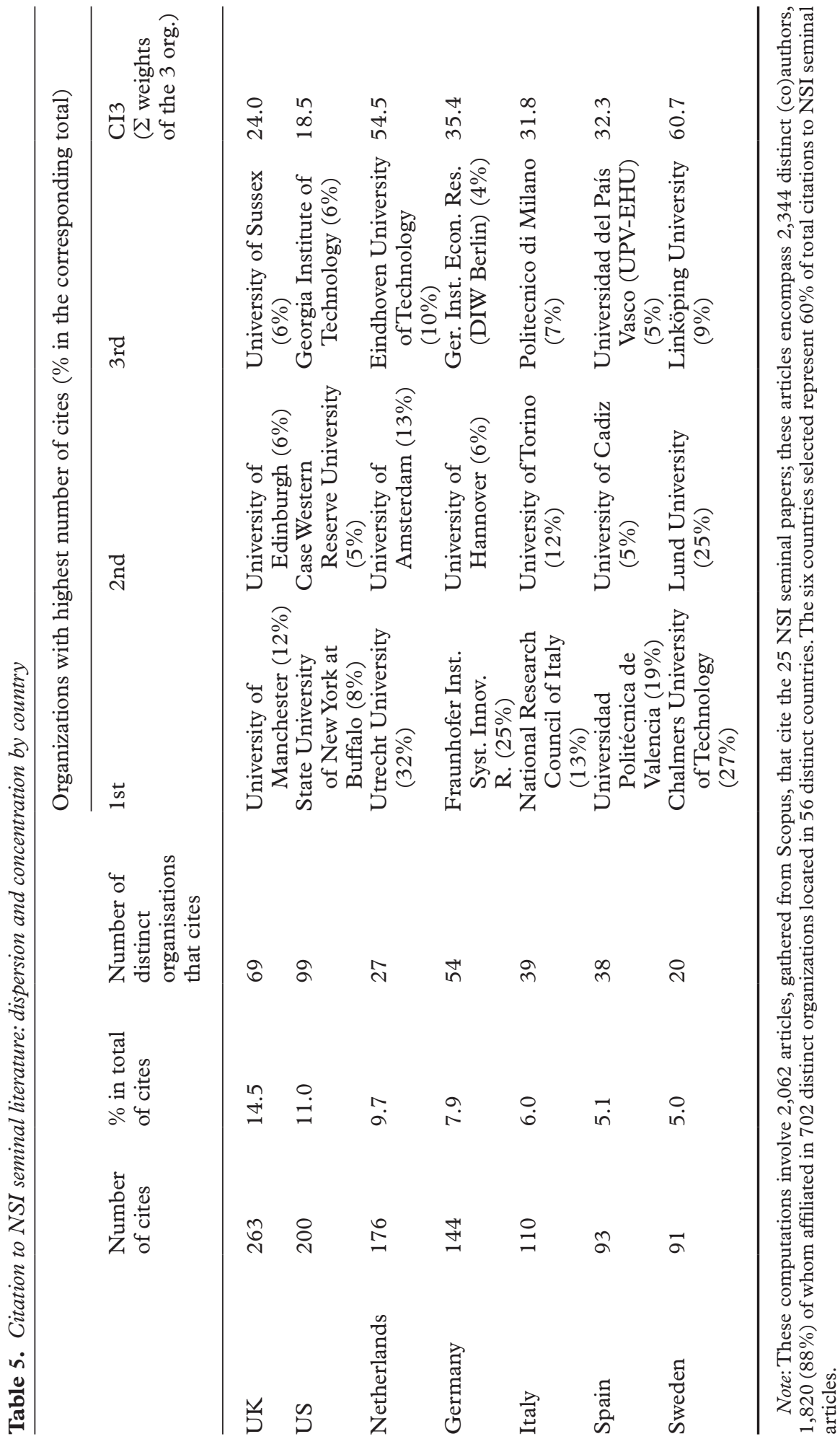


Amsterdam and Eindhoven (Chalmers, Lund, and Linköping), with Utrecht University (Chalmers) alone accounting for about a third of the corresponding total.

In the United States and United Kingdom, the influence of NSI seminal literature is quite dispersed and distributed among the relatively numerous organisations whose authors cite NSI literature in their published works. Notwithstanding, the University of Manchester (12\%) and the State University of New York at Buffalo (8\%) reveal a relatively higher influence from NSI seminal literature than do their national counterparts.

Considering institutions individually, the influence of NSI seminal literature, assessed by the number (and weight in total) of citations to this literature, is particularly notable in researchers affiliated with Utrecht University (Netherlands), Fraunhofer Institute (Germany) and the University of Manchester (UK) (see Figure S7 in the supplementary material). It is interesting to note that although Belgium, Austria and Denmark do not appear in Figure 7 as the most important outlet countries in terms of being influenced by NSI literature, the Catholic University of Louvain, Vienna University and Copenhagen Business School appear as relatively important locations of authors who cite NSI seminal papers, that is, that are influence by the NSI literature. The US-based schools are notably absent in this regard, indicating that none of the US schools are particularly influenced by the NSI literature in comparison to its European counterparts.

Indeed, detailing further the citation figures now in terms of authors (see Table S1 in the supplementary material), the importance of Utrecht University and Catholic University of Louvain is evident as 'hubs' of influence in the NSI literature. It should be noted that the range of influence of the NSI seminal articles goes beyond their original nucleus, in terms of both authors/institutions and area of study. In fact, from the outset, NSI has drawn mostly on the works of Chris Freeman (SPRU, University of Sussex/ IKE, Aalborg University/MERIT in Maastricht), ${ }^{13}$ Bengt-Åke Lundvall (University of Aalborg) and Richard Nelson (Columbia University), geographically centred in the United Kingdom, Denmark and United States, respectively; nowadays its influence strongly affects authors from institutions located in the Netherlands, Germany, Italy and Spain and has even extended beyond the European and North American regions, achieving an important resonance in Latin America and Asia (Figure 7).

Although the core research areas of the authors citing the NSI seminal papers are directly or indirectly linked to innovation studies, particularly remarkable is the influence that this literature has had on authors whose core research is related to regional related subject areas in general and economic geography in particular (David Doloreux, Franz Tödling and Staffan Jacobsson), managerial sciences (Koen Debackere), international business (Reinhilde Veugelers) or environmentally related issues (Marko Hekkert and Simona Negro). It is interesting to note that $31.8 \%$ of total citations made to NSI articles come articles published in outlets from regional related subject areas (see Figure 8). This means that this latter subject area is more 'influenced' by NSI literature than the other way around (recall the relative weight of citations made by NSI articles to journals from regional subject areas-Figure 6).

\footnotetext{
${ }^{13}$ It is important to note that it is highly probable that Freeman's most important work on NSI was done in a period when SPRU was no longer his main affiliation, although he remained closely connected to SPRU until the end of his life. Freemen stepped down as SPRU director in 1984 and afterwards the most longlasting affiliations were with the IKE group in Aalborg and MERIT in Maastricht (from 1988 onwards).
} 


\section{Page 28 of 34 A. A. C. Teixeira}

\section{Conclusions}

The development of national innovation systems is best studied as a historical process. (Fagerberg et al., 2009, p 431)

This NSI approach generally refers to the influence and evolution of production activities and the relationship with the institutional setting in knowledge generation, considering both informal institutions (such as trust) and formal arrangements (such as intellectual property rights or contract laws) (Lundvall, 2007). In a broad sense, this includes in a unique analytical framework the combination of more traditional aspects of vertical linkages in production systems - introducing learning-by-doing and learning-by-searching - with some micro-assumptions based on the chain-linked model of innovation (Kline and Rosenberg, 1986), the sources of innovation (Von Hippel, 1988) and the institutional dimension that enhances interactive learning (Lundvall et al., 2002). This approach is often considered useful as a general framework to study the differences between productive and research systems of countries, making it possible to analyse absorptive capacities and the learning capability of individuals and organisations that take part in the innovation processes (Álvarez and Marín, 2010).

Emerging from an older stream of literature of the evolutionist school of economics on industrial 'catching-up' of late-comer countries (Freeman, 1987), NSI was initially proposed as a possible alternative to the macro-economic models of growth (Silva, 2009; Guennif and Ramani, 2012).

The NSI perspective and evolutionary economics with regards to their view of the firm share an emphasis on the importance of the institutional context, or more generally, of the social context (Yoon and Hyun, 2009). As Hauknes (1999: 1) stated, NSI 'reflects Marx's broad conceptions of the economy as a social process', being, as it was clearly demonstrated in this article, multi-disciplinary in scope. This is line with the conviction that a matured understanding of economic behaviour and its driving forces cannot be achieved without the appropriate consideration of a wider social setting.

Intersecting with the NSI literature is the need for active government involvement, nationally, locally and even globally, in terms of industrial policy in general and innovation, science and technology, and educational and regional policies in particular. Indeed, one of the most striking features of innovation policy discussions in national governments and international policy organisations has been the adoption of the terminology of systems thinking and in particular the language of NSI (Dodgson et al., 2011). The NSI approach indicates that the catch-up trajectories of countries will be path-dependent, and as different nations pursue different strategies for the accumulation of capabilities, they will attain different results. Therefore, using the NSI framework, we can explore why at certain points of time countries with similar resource structures and investment patterns have had different trajectories in accumulation of industrial capabilities.

The evolution over time of articles published on NSI has been quite irregular, appearing in the scientific sphere in 1995, when the Cambridge Fournal of Economics published a special issue on the topic. Since its peak in 1995, publications on NSI have had a downward trend, which became particularly marked after 2004, revealing perhaps some exhaustion of (scientific and political) interest in the matter of NSI.

The NSI approach remains more of a conceptual framework than a theory (Guennif and Ramani, 2012), open to many forms of interpretations and investigations (Edquist, 1997, 2001; Lundvall, 1998), lacking a formalised and analytical frame able to establish 
guidelines on how to pursue and implement the (increasing) empirical work in the area. Indeed, the majority of the articles published on NSI between 1991 and 2010 were descriptive, and the weight of formal contributions not only remained small but presented a worrying downward trend.

Within descriptive topics, science and technology and policy-oriented articles lost importance in favor of science-industry/technology transfer-related papers. Such a trend is likely to be associated to significant scientific and political interest in university-firm relations (Gokhberg et al., 2009; Grimaldi et al., 2011) and open innovation issues (Wang et al., 2012).

Historical accounts, which lie at the heart of the evolutionary school of economics (Reid and Ramani, 2012), also showed substantial progress. The decrease in descriptive science and technology and policy-oriented articles and an increase in detailed historical accounts of NSI seem, to some extent, to curb criticisms based on the view that applications of the NIS approach are often too static, descriptive and mechanical, and focus disproportionately on science and technology as opposed to other loci of innovation (Dodgson et al., 2011). Indeed, historical accounts in line with Freeman tend to emphasise the dynamic, emergent and evolving nature of systems and the multiple and distributed sources of knowledge for innovation (Lundvall, 2007).

I found that the NSI literature has become increasingly empirically grounded in the past 20 years. This might be seen as a 'virtuous' evolution as 'in order to move towards a workable theory of NSI, and arrive at a typology of systems, with an understanding of their concomitant impact on knowledge accumulation, more empirical studies are called for' (Guennif and Ramani, 2012, p 431). However, the small and decreasing weight of formal (and formal plus empirical) studies in the NSI literature may jeopardise the goal of guaranteeing that 'good' policies are implemented. Indeed, it is critical that the design of policies be based on formal constructs which lend themselves to empirical evaluation (Cruz and Teixeira, 2010). More specifically, 'simple rhetorical [appreciative] devices should be avoided and instead comprehensive and in-depth analyses ... should, to some extent, seek to employ the analytical and methodological thoroughness of science approaches, by making the 'micro foundations of the frameworks' explicit and clearly defined' (McCann, 2007, p 1215).

The evidence on emergent economies has been increasing substantially, most notably focussing on China, South Korea and Taiwan. Even so, a vast geographical area of the world has yet to be the object of published articles on NSI. Most of the published articles have addressed the reality of highly developed countries such as the United States, Germany, France and Japan. Less developed countries from Africa and the Middle East are regretfully absent. Thus, issues such as the role technology and innovation can play in reducing poverty cannot be properly understood (Lorentzen, 2009).

In terms of identifying the 'roots' of NSI, not surprisingly, Richard Nelson, BengtÅke Lundvall and Chris Freeman emerge as its founding fathers. Despite the undeniable relevance of these authors in the emergence and development of the NSI concept, one could argue that Freeman's influence is paramount. Besides the 'most original and influential contribution was his strong advocacy of a holistic and systemic approach to the understanding of innovation (. . .) us[ing] the concept of "national system of innovation" to account for ... interdependencies, which are, of course, crucial to be aware of when designing science, technology and innovation policies' (Fagerberg et al., 2011, p 907), Freeman was also the founding editor of Research Policy (1971) and the first director of SPRU, Science and Technology Policy Research (1966). SPRU was 


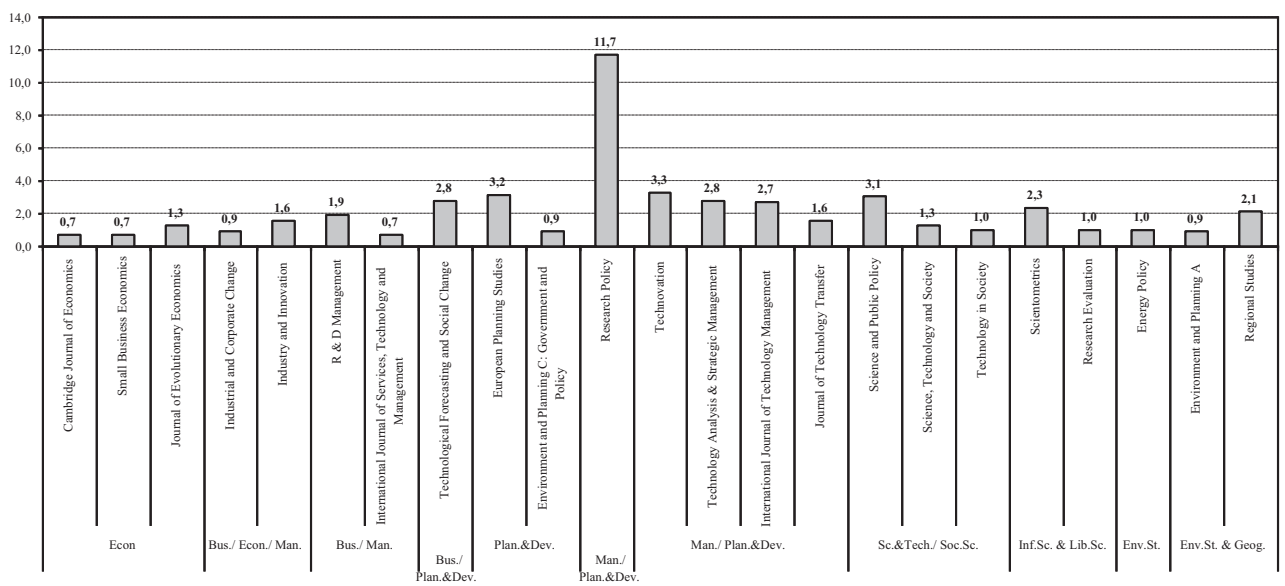

Fig. 8. The influence of NSI seminal articles by journals (\% total citation to NSI seminal articles). Notes: The 2,062 articles citing the NSI seminal papers were published in 475 distinct journals; $13 \%$ of the journals that published articles citing NSI seminal papers account for only one citation each, whereas $7 \%$ of the journals cites 10 and more time NSI seminal papers.

The figure depicts 24 journals that are responsible for half of the total citations to NSI.

one of the first trans-disciplinary research institutions in the field, which has been a true 'incubator' of leading authors in innovation studies in general and NSI in particular over the past two decades. It is interesting to note that recently (January 2012), SPRU ranked number 6 on a list of the top 30 science and technology think-tanks worldwide. ${ }^{14}$

The three major scientific roots of the NSI literature were published in the late 1980s and early 1990s: Technical Change and Economic Theory (Dosi et al), National Systems of Innovation (Lundvall) and National Innovation Systems: A Comparative Analysis (Nelson). Among the top cited articles, one by Freeman stands out: 'The National System of Innovation in historical perspective' (1995).

This analysis of the roots of the NSI literature has highlighted its clear multi-disciplinary traits as a fertile and rich crossroads of concepts, analytical frameworks and methods from the management and business, regional science and economics fields of research.

The influence of the NSI literature, measured by the citations to NSI seminal articles, is quite widespread geographically, encompassing almost 60 countries worldwide. An interesting finding is that the range of influence of NSI seminal articles goes beyond its original nucleus, in terms of both authors/institutions and area of study. Indeed, whereas the roots are quite geographically centered in the United Kingdom, Denmark and United States, being more marked in Europe than the United States, its influence is more noticeable on authors from institutions located in the Netherlands, Germany, Italy and Spain, having also extended to Latin America and Asia. Additionally, it was demonstrated that the NSI literature has had substantial impact in other literatures,

\footnotetext{
${ }_{14}$ See http://www.gotothinktank.com/wp-content/uploads/2012/01/2011-Global-Go-To-Think-TanksReport.pdf.
} 
namely, in business and management and regionally related studies (i.e., economic geography, planning, environment and urban studies).

Despite the considerable theoretical progress made, some argue (e.g., Allard et al., 2012; Guan and Chen, 2012) that the NSI literature fails to empirically investigate the internal process of transformation for innovative investment and the participating effects of the policy-based innovation environment based on systems thinking, particularly in emerging or less developed countries (Asakawa and Som, 2008) or in a context of internationalising national innovation systems (Carlsson, 2006).

The bibliometric exercise performed here has led me to agree with Dodgson et al. (2011), who argue that the problems with the NSI approach have not prevented it from influencing policy thinking through its capacity to produce a shared framework of analysis, by spanning academic and policy boundaries and providing a versatile tool for decision making. However, as highlighted, it is critical that the design of policies be based on detailed, in-depth, and systemic historical analyses and on formal constructs that lend themselves to empirical evaluation. The failure of the NSI studies approach in achieving an improved 'internal methodological consistency' will result in ill-defined policy design and evaluations in this area. Moreover, to neglect the contribution that the study of distinct (less developed) NSI brings to economics (of innovation) is to fail to address Freeman's (1992) notable enterprise of transforming the 'dismal science' of economics into 'the economics of hope'.

\section{Bibliography}

Adler, E. and Haas, P. M. 1992. Conclusion: epistemic communities, world order, and the creation of a reflective research program, International Organization, vol. 46, no. 1, 367-90

Albuquerque, E. M. 2007. Inadequacy of technology and innovation systems at the periphery, Cambridge fournal of Economics, vol. 31, 669-90

Alcorta, L. and Peres, W. 1998. Innovation systems and technological specialization in Latin America and the Caribbean, Research Policy, vol. 26, no. 7-8, 857-81

Allard, G., Martinez, C. A. and Williams, C. 2012. Political instability, pro-business market reforms and their impacts on national systems of innovation, Research Policy, vol. 41, no. 3, 638-51

Álvarez, I. and Marín, R. 2010. Entry modes and national systems of innovation, fournal of International Management, vol. 16, 340-53

Asakawa, K. and Som, A. 2008. Internationalization of R\&D in China and India. Conventional wisdom versus reality, Asia Pacific fournal of Management, vol. 25, 375-94

Balzat, M. and Hanusch, H. 2004. Recent trends in the research on national innovation systems, Fournal of Evolutionary Economics, vol. 14, 197-210

Baskaran, A. and Muchie, M. 2009. Exploring the impact of national system of innovation on the outcomes of foreign direct investment, International fournal of Technological Learning, Innovation and Development, vol. 2, no. 4, 314-45

Carlsson, B. 2006. Internationalization of innovation systems: a survey of the literature, Research Policy, vol. 35, 56-67

Choung, J.-Y. and Hwang, H.-R. 2000. National Systems of Innovation: institutional linkages and performances in the case of Korea and Taiwan, Scientometrics, vol. 48, no. 3, 413-26

Cohen, W. M. and Levinthal, D. A. 1990. Absorptive Capacity: A New Perspective on Learning and Innovation, Administrative Science Quarterly, vol. 35, 128-52

Cruz, S. and Teixeira, A. A. C. 2010. The evolution of the clusterl: shedding light on the regional science-regional studies debate, Regional Studies, vol. 44, no. 9, 1263-88

Dosi, G., Freeman, C., Nelson, R., Silverberg, G. and Soete, L. 1988. Technical Change and Economic Theory, London and New York, Pinter Publisher

Dodgson, M., Hughes, A., Foster, J. and Metcalfe, S. 2011. Systems thinking, market failure, and the development of innovation policy: the case of Australia, Research Policy, vol. 40, 1145-56 


\section{Page 32 of 34 A. A. C. Teixeira}

Du, Y. and Teixeira, A. A. C. 2012. A bibliometric account of Chinese economics research through the lens of the China Economic Review, China Economic Review, vol 23, no. 4, 743-62

Edquist, C. (ed.). 1997. Systems of Innovation-Technologies, Institutions and Organizations, London, Pinter Publishers/Cassell Academic

Edquist, C. 2001. The systems of innovation approach and innovation policy: an account of the state of the art, paper presented at the DRUID Conference, National Systems of Innovation, Institutions and Public Policy, Aalborg, 12-15 June

Edquist, C. 2005. Systems of innovation - perspectives and challenges, chapter 7 in Fagerberg, J., Mowery, D. C. and Nelson, R. (eds.), Oxford Handbook of Innovation, Oxford, Oxford University Press

Eichhorst, W., Profit, S. and Thode, E. (eds.). 2001. Benchmarking Deutschland: Arbeitsmarkt und Beschäftigung. Bericht der Arbeitsgruppe Benchmarking und der Bertelsmann Stiftung, Berlin, Springer-Verlag

Eom, B.-Y. and Lee, K. 2010. Determinants of industry-academy linkages and, their impact on firm performance: the case of Korea as a latecomer in knowledge industrialization, Research Policy, vol. 39, no. 5, 625-39

Eparvier, P. 2005. Methods of evolutionism and rivalry with neoclassical analysis. The example of the National System of Innovation concept, fournal of Economic Methodology, vol. 12, no. $4,563-79$

Fagerberg, J. 2003. Schumpeter and the revival of evolutionary economics: an appraisal of the literature, fournal of Evolutionary Economics, vol. 13, 125-59

Fagerberg, J., Fosaas, M., Bell, M. and Martin, B. 2011. Christopher Freeman: social science entrepreneur, Research Policy, vol. 40, 897-916

Fagerberg, J., Mowery, D. C. and Verspagen, B. 2009. The evolution of Norway's national innovation system, Science and Public Policy, vol. 36, no. 6, 431-44

Fagerberg, J. and Sapprasert, K. 2011. National innovation systems: the emergence of a new approach, Science and Public Policy, vol. 38, no. 9, 669-79

Fagerberg, J. and Srholec, M. 2008. National innovation systems, capabilities and economic development, Research Policy, vol. 37, 1417-35

Fagerberg, J. and Verspagen, B. 2009. Innovation studies-the emerging structure of a new scientific field, Research Policy, vol. 38, 218-33

Freeman, C. 1987. Technology Policy and Economic Performance: Lessons from Fapan, London, Pinter

Freeman, C. 1992.The Economics of Hope: Essays on Technical Change and Economic Growth, London, Pinter

Freeman, C. 1995. The 'National System of Innovation' in historical perspective, Cambridge fournal of Economics, vol. 19, 5-24

Freeman, C. 1997. The diversity of national research systems, chapter 1 in Barre, R., Gibbons, M., Maddox, J., Martin, B. and Papon, P. (eds.), Science in Tomorrow's Europe, Paris, Economica International

Freeman, C. 2002. Continental, national and sub-national innovation systems-complementarity and economic growth, Research Policy, vol. 31, 191-211

Freeman, C. 2004. Technological infrastructure and international competitiveness, Industrial and Corporate Change, vol. 13, no. 3, 541-69

Furman, J. L., Porter, M. E. and Stern, S. 2002. The determinants of national innovative capacity, Research Policy, vol. 31, no. 6, 899-933

Godin, B. 2009. National Innovation System: the system approach in historical perspective, Science Technology Human Values, vol. 34, no. 4, 476-501

Godinho, M., Mendonça, S. and Pereira, T. 2004. Towards a taxonomy of innovation systems, paper presented at 2nd Globelics Conference, Innovation Systems and Development: Emerging Opportunities and Challenges, Beijing, 16-20 October

Gokhberg, L., Kuznetsova, T. and Zaichenko, S. 2009. Towards a new role of universities in Russia: prospects and limitations, Science and Public Policy, vol. 36, no. 2, 121-26

Grimaldi, R., Kenney, M., Siegel, D. S. and Wright, M. 2011. 30 years after Bayh-Dole: reassessing academic entrepreneurship, Research Policy, vol. 40, no. 8, 1045-57

Groenewegen, J. and van der Steen, M. 2006. The evolution of National Innovation Systems, Fournal of Economic Issues, vol. 40, no. 2, 277-85 


\section{Bibliometric account of NSI}

Guan, J. and Chen, K. 2012. Modeling the relative efficiency of national innovation systems, Research Policy, vol. 41, 102-15

Guennif, S. and Ramani, S. V. 2012. Explaining divergence in catching-up in pharma between India and Brazil using the NSI framework, Research Policy, vol. 41, 430-41

Haas, E. B. 1990. When Knowledge Is Power:Three Models of Change in International Organizations, Berkeley, University of California Press

Haas, P. M. 1992. Introduction: epistemic communities and international policy coordination, International Organization, vol. 46, no. 1, 1-35

Hauknes, J. 1999. 'Innovation systems and capabilities', STEP Working paper series no. A1099, STEP Group, Studies in Technology, Innovation and Economic Policy, available at http:// econpapers.repec.org/RePEc:stp:workin:a1099 (date last accessed 3 June 2013)

Hee, C. H. and Hirasawa, R. 1998. Changes in Japanese government policies to be a frontrunner in science and technology, Science and Public Policy, vol. 25, no. 1, 47-54

Intarakumnerd, P., Chairatana, P.-A. and Tangchitpiboon, T. 2002. National innovation system in less successful developing countries: the case of Thailand, Research Policy, vol. 31, no. 8-9, 1445-57

Kline, S. J. and Rosenberg, N. 1986. An overview of innovation, pp. 275-305 in Landau, R. and Rosenberg, N. (eds.), The Positive Sum Strategy, Washington, DC, National Academy Press

Liu, X. and White, S. 2001. Comparing innovation systems: a framework and application to China's transitional context, Research Policy, vol. 30, no. 6, 1091-114

Lorentzen, J. 2009. Learning by firms: The black box of South Africa's innovation system, Science and Public Policy, vol. 36, no. 1, 33-45

Lundvall, B.-Å. 1985 (ed.). Product Innovation and User-Producer Interaction, Aalborg, Aalborg University Press

Lundvall, B.-Å. 1992 (ed.). National Systems of Innovation: Towards a Theory of Innovation and Interactive Learning, London, Pinter Publishers

Lundvall, B.-Å. 1998. Why study national systems and national styles of innovation?, Technology Analysis \& Strategic Management, vol. 10, no. 4, 407-22

Lundvall, B.-A. 2000. Understanding the role of education in the learning economy: the contribution of economics, in OECD-CERI, Knowledge Management in the Learning Society, Paris, OECD

Lundvall, B.-Å. 2002. Innovation, Growth and Social Cohesion: The Danish Model, Cheltenham, Edward Elgar

Lundvall, B.-A. 2003. National innovation systems: history and theory, pp. 872-81 in Elgar Companion to Neo-Schumpeterian Economics, Cheltenham, Edward Elgar

Lundvall, B.-A. 2004. Introduction to 'technological infrastructure and international competitiveness' by Christopher Freeman, Industrial and Corporate Change, vol. 13, no. 3, 531-39

Lundvall, B.-Å. 2007. National Innovation Systems-analytical concept and development tool, Industry and Innovation, vol. 14, no. 1, 95-119

Lundvall, B.-Å., Johnson, B., Andersen, E. S. and Dalum, B. 2002. National systems of production, innovation and competence building, Research Policy, vol. 31, 213-31

Martin, B. and Bell, M. 2011. Editorial-in memory of Chris Freeman founding editor of Research Policy, 1971-2003, Research Policy, vol. 40, no. 7, 895-96

McCann, P. 2007. Observational equivalence? Regional studies and regional science, Regional Studies, vol. 41, 1209-21

Miettinen, R. 2002. National Innovation System, Scientific Concept or Political Rhetoric, Helsinki, Edita

Mirowski, P. 2002. Machine Dreams: Economics Becomes a Cyborg Science, Cambridge, Cambridge University Press

Nasierowski, W. and Arcelus, F. 1999. Interrelationships among the elements of national innovation systems: a statistical evaluation, European fournal of Operational Research, vol. 119, no. 2, 235-53

Nasierowski, W. and Arcelus, F. 2000. On the stability of countries' national technological systems, pp. 97-111 in Zanakis, S., Doukidis, G. and Zopounidis, C. (eds.), Decision Making: Recent Developments and Worldwide Applications, Kluwer, Dordrecht

Nasierowski, W. and Arcelus, F. J. 2003. On the efficiency of national innovation systems, SocioEconomic Planning Sciences, vol. 37, no. 3, 215-234

Nelson, R. 1984. High-Technology Policies-A Five-Nation Comparison, Washington, DC, American Enterprise Institute 


\section{Page 34 of 34 A. A. C. Teixeira}

Nelson, R. (ed.). 1993. National Innovation Systems: A Comparative Analysis, Oxford, Oxford University Press

Nelson, R. and Winter, S. 1982. An Evolutionary Theory of Economic Change, Cambridge, Harvard University Press

OECD (Organisation for Economic Co-operation and Development). 1998. Technology, Productivity and Fob Creation: Best Policy Practices, Paris, OECD

OECD. 2002. Dynamising National Innovation Systems, Paris, OECD

Polt, W., Rammer, C., Schartinger, D., Gassler, H. and Schibany, A. 2001. Benchmarking industry-science relations: the role of framework conditions, Science and Public Policy, vol. 28, no. 4, 247-58

Porter, M. E. 1990. The Competitive Advantage of Nations, New York, Free Press

Porter, M. and Stern, S. 2002. National innovative capacity, pp. 102-119 in World Economic Forum: The Global Competitiveness Report 2001-2002, New York, Oxford University Press

Radosevic, S. 1999. Transformation of science and technology systems into systems of innovation in central and eastern Europe: the emerging patterns and determinants, Structural Change and Economic Dynamics, vol. 10, no. 3-4, 277-320

Ramani, S.V. and De Looze, M.-A. 2002. Country-specific characteristics of patent applications in France, Germany and the UK in the biotechnology sectors, Technology Analysis and Strategic Management, vol. 14, no. 4, 457-80

Reid, S. E. and Ramani, S. V. 2012. The harnessing of biotechnology in India: which roads to travel?, Technological Forecasting \&o Social Change, vol. 70, 648-64

Rongping, M. and Wan, Q. 2008. The development of science and technology in China: A comparison with India and the United States, Technology in Society, vol. 30, nos. 3-4, 319-29

Samara, E., Georgiadis, P. and Bakouros, I. 2012. The impact of innovation policies on the performance of national innovation systems: a system dynamics analysis, Technovation, vol. 32, no. $11,624-38$

Sharif, N. 2006. Emergence and development of the National Innovation Systems concept, Research Policy, vol. 35, 745-66

Silva, E. G., Teixeira, A. A. C. 2008. Surveying structural change: seminal contributions and a bibliometric account, Structural Change and Economic Dynamics, vol. 19, no. 4, 273-300

Silva, S. T. 2009. On evolutionary technological change and economic growth: Lakatos as a starting point for appraisal, Fournal of Evolutionary Economics, vol. 19, no. 1, 111-35

Silva, S. T. and Teixeira, A. A. C. 2009. On the divergence of evolutionary research paths in the past fifty years: a comprehensive bibliometric account, fournal of Evolutionary Economics, vol. 19 , no. 5, 605-42

Sornn-Friese, H. 2000. Frontiers of research in industrial dynamics and National Systems of Innovation, Industry and Innovation, vol. 7, no. 1, 1-13

Sun,Y. and Liu, F. 2010. A regional perspective on the structural transformation of China's national innovation system since 1999, Technological Forecasting E Social Change, vol. 77, 1311-21

Teixeira, A. A. C. 2011. Mapping the (in)visible college(s) in the field of entrepreneurship, Scientometrics, vol. 89, no. 1, 1-36

Toivanen, H. and Ponomariov, B. 2011. African regional innovation systems: bibliometric analysis of research collaboration patterns 2005-2009, Scientometrics, vol. 88, 471-93

Van Looy, B., Debeckere, K., Callaert, J., Tijssen, R. and Van Leeuwen, T. 2006. Scientific capabilities and technological performance of national innovation systems: an exploration of emerging industrial relevant research domains, Scientometrics, vol. 66, no. 2, 295-310

Viotti, E. B. 2002. National Learning Systems A new approach on technological change in late industrializing economies and evidence from the cases of Brazil and South Korea, Technological Forecasting \& Social Change, vol. 69, no. 7, 653-80

von Hippel, E. 1988. The Sources of Innovation, New York, Oxford University Press

Wang, Y., Vanhaverbeke, W. and Roijakkers, N. 2012. Exploring the impact of open innovation on national systems of innovation - a theoretical analysis, Technological Forecasting and Social Change, vol. 79, no. 3, 419-28

Weintraub, R. 2002. How Economics Became a Mathematical Science, Durham, NC, Duke University Press

Yoon, W. and Hyun, E. 2009. How relevant and useful is the concept of National Systems of Innovation?, fournal of Technology Management and Innovation, vol. 4, no. 3, 1-13 